\title{
Tailoring Organic Apples by Cultivar Selection, Production System, and Post-harvest Treatment to Improve Quality and Storage Life
}

\author{
Ibrahim I. Tahir ${ }^{1}$ \\ Department of Plant Breeding and Biotechnology, Swedish University of \\ Agricultural Sciences, P.O. Box 104, 23053 Alnarp, Sweden
}

\author{
Hilde Nybom \\ Department of Plant Breeding and Biotechnology-Balsgård, Swedish \\ University of Agricultural Sciences, Fjälkestadsvägen 459, 29194 \\ Kristianstad, Sweden
}

Additional index words. Apple, Malus $\times$ domestica, optimal harvesting date, orchard management, organic production, post-harvest treatment

\begin{abstract}
A series of pre- and post-harvest experiments were conducted to enhance apple tree productivity and improve fruit quality and storage life by altering production system and post-harvest treatments in an organic orchard. Increasing the light distribution and carbohydrate uptake (summer pruning and covering the orchard ground with reflective textile) improved tree productivity, fruit color, content of anthocyanin, ascorbic acid, and total phenolic compounds and reduced incidence of fungal storage diseases. Optimal harvesting time could be determined from the starch index in some cultivars, whereas the Streif index [firmness (soluble solids concentration $\times$ starch hydrolysis score $)^{-1}$ ] was more accurate for other cultivars. In yet others, titratable acidity and flesh firmness also produced important information. By contrast, soluble solids concentration and skin color are not useful as a result of their sensitivity to weather conditions and light intensity. Post-harvest fruit treatment with hot water ( $46{ }^{\circ} \mathrm{C}$ for 120 seconds) decreased fungal decay during storage in two cultivars, whereas spraying the fruit with $10 \%$ ethanol decreased fungal decay in all investigated cultivars. Optimization of storage conditions [cultivar-specific controlled atmosphere (CA) and ultra-low oxygen (ULO) storage procedures] maintained fruit quality and reduced the amount of fungal decay.
\end{abstract}

As a result of the high market value and increasing interest from consumers, efforts have been made to promote organic apple production and solve some of the problems facing this system such as application of integrated pest and groundcover management (Lima et al., 2003; Weibel, 2002) and fertilization regimes (Herencia et al., 2007). Apple is the main commercial fruit crop in Sweden and is grown on 1440 ha, of which only $10 \%$ are organic. Orchard productivity is comparatively low and varies between 12 and 20 t.ha ${ }^{-1}$ (Ascard et al., 2010; Jönsson, 2007). Because apple scab is the most detrimental disease in cool and moist production areas, cultivars with monogenic (vertical) or polygenic (horizontal) resistance to this disease have received considerable attention. Many of these scab-resistant cultivars, however, suffer from poor skin color at harvest, low

Received for publication 31 Aug. 2012. Accepted for publication 27 Nov. 2012.

Financial support was received for this study from SLU EkoForsk.

${ }^{1}$ To whom reprint requests should be addressed; e-mail ibrahim.tahir@slu.se.
(Lafer, 2006). Accurate determination of an optimum harvesting date is therefore important for maintaining fruit quality and minimizing losses during storage. Elaborate harvesting indices based on changes in physical and biochemical properties like internal ethylene concentration and respiration rate (Delong et al., 2009; Echeverría et al., 2002; Peirs et al., 2004) are accurate but time-intensive. More practical and simple indices, like starch conversion to sugar, fruit softening, and color development (Peirss et al., 2004; Willats et al., 2001), are needed but must be correlated with the known accurate indices. Also, each index has to be evaluated for specific cultivar and environment effects.

In apple, various post-harvest treatments are commonly applied to control fungal decay and maintain fruit quality during storage. For organically produced fruit, non-chemical methods have been used like post-harvest heating (Paull and Chen, 2000; Tahir et al., 2009). Success of dipping the fruit in warm water however depends on cultivar and exposure period (Conway et al., 2004; Maxin et al., 2012). Post-harvest decay can also be reduced by spraying with ethanol immediately after harvest, which denaturizes proteins in fungal cells and can delay fruit ripening (Karabulut et al., 2004; Zhang et al., 2007).

Finally, storage in CA including ULO helps to maintain fruit quality and, especially in the case of organic fruit, protects against fungal diseases. Unfavorable CA conditions can, however, induce physiological disorders (e.g., flesh browning), enhance susceptibility to decay, and shorten shelf life (de Castro et al., 2007; Fawbush et al., 2008). Thus, optimum CA conditions must be investigated for cultivars used in organic apple production (Delate et al., 2003).

The purpose of this work was to investigate the feasibility of improving yield, quality, and storage life of some organically grown apple cultivars with known scab resistance by optimizing procedures in four different areas: orchard management, determination of correct harvesting time, application of post-harvest fruit protection, and use of storage conditions.

\section{Materials and Methods} be improved by summer pruning of the trees and covering the orchard ground with reflective materials (Blanke, 2008; Funke and Blanke, 2005; Tahir et al., 2005). Both production practices provide a better light distribution in the canopy and thus enhance the red skin color. Pruning reduces competition between fruit and vegetative growth, improving carbohydrate accumulation and post-harvest internal quality and storability. However, in a previous study, we found that using each practice alone did not achieve significant effects (Tahir et al., 2008).

The stage of fruit maturation at the time of picking influences the overall dessert quality of apples both at harvest and after storage (Rizzolo et al., 2006; Vielma et al., 2008) as well as the ability to withstand fungal attacks

\section{Plant materials}

Eight organically grown apple cultivars, recently developed and potentially important for areas with a cool climate, 'Agra' [Latvia, 'Quinte' $\times$ ('Tallinna Pirnoun' $\times$ 'Suislepper'), good field resistance against apple scab], 'Dayton' [USA, NJ123249 × PRI1235-100 (including, e.g., 'Melba', 'Jonathan', and 'Rome Beauty'), Vf resistance against apple scab], 'Delorina' (France, 'Grifer' X 'Florina', Vf resistance), 'Eir' (Norway, 'Katja' $\times$ 'Buckley's Giant', good field resistance against apple scab), 'Ella' (Latvia, unknown pedigree, good field resistance against apple scab), 'Santana' (The Netherlands, 'Elstar' $\times$ 'Priscilla', Vf resistance), 'Sultanat' (Kazakhstan, 'Reinette 
de Burchardt' open-pollinated, good field resistance against apple scab), and 'Zarya Alatau' (Kazakhstan, 'Reinette d'Orleans' open-pollinated, good field resistance against apple scab), were used, either all or a subset, in four different experiments in an organic orchard in Kivik, southeastern Sweden (lat. $\approx 55^{\circ} \mathrm{N}$ ). Trees on rootstock M26 had been planted at $1.25 \times 4 \mathrm{~m}$ (in total 2000 trees/ha) in 1999 and trained according to the super spindle system. Pruning was performed each year in early April to maintain this shape. The orchard was fertilized each year (Bina blue $6 \mathrm{~N}: 1 \mathrm{P}: 12 \mathrm{~K}$, Garta, Sweden) with $300 \mathrm{~g}$ per tree in May and with $116 \mathrm{~g}$ per tree in June. Monthly soil cultivation was conducted with a rotary hoe rototiller during April to July. Plant protection measures were applied according to the regulations for commercial organic apple production defined by the Swedish Board of Agriculture (SJV). Neither irrigation nor bloom or fruit thinning was undertaken to reflect commonly applied orchard management in Sweden. The orchard was divided into two parts.

\section{Pre-harvest practices: one experiment}

Expt. 1: Orchard management: summer pruning and reflective mulch. The first part of the orchard included 24 trees per each of six cultivars ('Dayton', 'Delorina', 'Ella', 'Santana', 'Sultanat', and 'Zarya Alatau'). Trees were arranged in three blocks to create a completely randomized block design (eight trees per block and cultivar). In each block, four trees were treated according to standard practice (only early April pruning, no ground coverage). The other four trees were summer pruned at 10 to 15 July each year, and the ground under these trees was covered with a reflective textile (white sheet, $0.6 \mathrm{~mm}$ thick and $2 \mathrm{~m}$ wide; Lotico, Sweden) during 15 July to 15 Sept. Light penetration within the canopy was estimated at $1500 \mathrm{HR}$ local time on a sunny day once a week during July to August in 2009 and 2010. These measurements were conducted at the center of the trunk, from four directions along the crown and $70 \mathrm{~cm}$ above the ground, using a light meter (L1-188; L1-COR, Frederickson, Copenhagen, Denmark). Full sunlight was measured (at the same time and height) in a free area (between rows). Sunlight penetration (percent) was calculated as the amount of sunlight that reached the orchard floor and midcanopy compared with full sunlight. The fruits were harvested at a pre-climacteric stage with ethylene production at 0.1 to $0.3 \mu \mathrm{L} \cdot \mathrm{L}^{-1} \cdot \mathrm{kg}^{-1} \cdot \mathrm{h}^{-1}$, firmness $\approx 8.0 \mathrm{~kg} \cdot \mathrm{cm}^{-2}$, and starch staining 4 on a 10 -point scale, counted, and weighed. A sample of 25 fruit was picked from the inside and outside of each tree (a total of 100 fruit per block and cultivar), stored in cold air $\left[+2{ }^{\circ} \mathrm{C}\right.$ and $90 \%$ relative humidity $(\mathrm{RH})$ ] for four months followed by 1 week in a plastic chamber at $18 \pm 2{ }^{\circ} \mathrm{C}$ and $80 \%$ RH. Fruit quality parameters were investigated both at harvest and after storage when the fruit were also screened for physiological disorders and storage rots (see subsequently).

\section{Post-harvest practices: three experiments $(2,3$, and 4$)$}

The second part of the orchard included 15 trees of each of the eight cultivars ('Agra', 'Dayton', 'Delorina', 'Eir', 'Ella', 'Santana', 'Sultanat', and 'Zarya Alatau'). Trees were arranged in three blocks as a completely randomized block design (five trees per block and cultivar). Fruit for three experiments $(2,3$, and 4$)$ were picked in this part.

Expt. 2: Determination of optimal harvest date. Two fruit were picked each year from the outside and inside, respectively, of each tree in the second part of the orchard (10 fruit per block and cultivar) at three times a week for a total of 4 weeks per cultivar, starting at 95 d ('Agra'), 100 d ('Eir'), 105 d ('Ella'), 120 d ('Dayton', 'Santana', and 'Zarya Alatau') and $125 \mathrm{~d}$ ('Delorina' and 'Sultanat') after full bloom. The starting days were chosen from experiences in previous years in the same orchard. The 30 fruits were analyzed for several parameters commonly used for the development of a maturity index as described below. Weekly averages were used for the harvesting indices in the statistical analyses, and ethylene production was used as a standard method as a result of its higher accuracy. Each year, a sample with eight fruits per tree and cultivar (total 40 fruits per block and cultivar) was picked early in the morning (to obtain cold fruit) at weekly intervals for a total of four times a year and stored in cold air $\left(+2{ }^{\circ} \mathrm{C}\right.$ and $\left.90 \% \mathrm{RH}\right)$ for four months followed by 1 week in a plastic chamber at $18 \pm 2{ }^{\circ} \mathrm{C}$ and $80 \%$ RH. Percentage fruit with physiological disorders and fungal decay as well as fruit quality were estimated after storage as described below.

Expt. 3: Post-harvest treatment with heating and ethanol. In 2009 and 2010, four cultivars ('Agra', 'Dayton', 'Eir', and 'Sultanat') in the second part of the orchard were used in this experiment. A sample of 120 apples per cultivar was picked from each block (24 fruit from each tree, total 360 fruits per cultivar) at a pre-climacteric stage with ethylene production at $0.1-0.3 \mu \mathrm{L} \cdot \mathrm{L}^{-1} \cdot \mathrm{kg}^{-1} \cdot \mathrm{h}^{-1}$, firmness $\approx 8.0 \mathrm{~kg} \cdot \mathrm{cm}^{-2}$, and starch staining 4 on a 10 -point scale. Apples were divided into three subsamples (40 fruits each); the first one was sprayed with an ethanol solution (Solveco, Stockholm, Sweden), 100 $\mathrm{mL} \cdot \mathrm{L}^{-1}$ using an airbrush sprayer (Iwata, Spraypal, Italy), the second was immersed in water for $120 \mathrm{~s}$ at $46^{\circ} \mathrm{C}$, and the third was left as a control without any treatment. All subsamples were stored in cold air $\left(+2{ }^{\circ} \mathrm{C}\right.$ and $90 \% \mathrm{RH}$ ) for 16 weeks followed by 1 week in a plastic chamber at $18 \pm 2{ }^{\circ} \mathrm{C}$ and $80 \% \mathrm{RH}$ before the percentage fruit with fungal decay (Colletotrichum spp. and Neofabraea spp.) was determined.

Expt. 4: Controlled atmosphere storage. Each year, a sample of 24 fruits was picked at a pre-climacteric stage from each tree in the second part of the orchard, resulting in a total of 120 fruit per block and 360 fruits per cultivar. The fruits were harvested at a preclimacteric stage with ethylene production at
$0.3 \mu \mathrm{L} \cdot \mathrm{L}^{-1} \cdot \mathrm{kg}^{-1} \cdot \mathrm{h}^{-1}$ and starch staining 4 on a 10-point scale. Fruit were transported to Balsgård, SLU, sorted for uniform size and absence of blemishes including bitter pit, and divided into four subsamples (30 fruits in each of the three blocks, i.e., 90 fruits per cultivar). One of the subsamples was placed in cold air $\left(+2{ }^{\circ} \mathrm{C}\right.$ and $\left.90 \% \mathrm{RH}\right)$, one each in two ULO storage chambers (ULO 1: $1.0 \mathrm{kPa}$ $\mathrm{O}_{2}$ and $1.0 \mathrm{kPaCO}$ and ULO 2: $1.0 \mathrm{kPa} \mathrm{O}_{2}$ and $2.0 \mathrm{kPa} \mathrm{CO}$ ) and one in a $\mathrm{CA}(\mathrm{CA}: 2.0$ $\mathrm{kPa} \mathrm{O}_{2}$ and $2.0 \mathrm{kPa} \mathrm{CO}_{2}$ ). CA and ULO storage was achieved in computer-controlled 350-L chambers (Ninolab, Upplands Väsby, Sweden) with gas composition established $3 \mathrm{~d}$ before placing the apples in the chambers. After five months in storage and 1 week in a plastic chamber at $18 \pm 2{ }^{\circ} \mathrm{C}$ and $80 \% \mathrm{RH}$, quality parameters as well as physiological disorders and fungal decay incidence were evaluated as described below.

\section{Analysis}

Analyses of maturity indices. In all experiments, the following maturity indices were estimated at harvest on fruit picked from outside and inside of each tree, three times a week, two for internal ethylene production and two for other indices (16 fruit per block and cultivar in Expt. 1 and 20 fruit per block and cultivar in the other three experiments):

1. Fruit coloration was measured using a chromometer, CR200, with an 8-mm diameter aperture (Minolta Ltd., Osaka, Japan). Measurements were conducted on three spots per apple and expressed as hue angle $\mathrm{h}^{\circ}$, where $0^{\circ}=$ red-purple, $90^{\circ}=$ yellow, $180^{\circ}=$ bluish green, and $270^{\circ}=$ blue (McGuire, 1992).

2. Firmness was measured on opposite, peeled sides, at the equator of each fruit, using a penetrometer (Model FT 327; Effigi, Italy; plunger diameter of $11.1 \mathrm{~mm}$, depth of $7.9 \mathrm{~mm}$ ) and results expressed as $\mathrm{kg} \cdot \mathrm{cm}^{-2}$.

3. Starch hydrolysis was evaluated by dipping a slice of the fruit, cut across the equator, in an iodine solution $(8.8 \mathrm{~g}$ potassium iodide and $2.2 \mathrm{~g}$ iodine per liter) for $1 \mathrm{~min}$. Starch staining was graded on a scale of 10: 1 = full color and $10=$ free of starch (no color).

4. Titratable acidity (TA) was measured on juice extracted by a juicer (Phillips HR 1854, The Netherlands) from composite samples of segments of two fruits per tree using a titration unit (Titroline Easy; SCHOTT Instr. GmbH, Germany) and $0.1 \mathrm{M} \mathrm{NaOH}$ to an end point of $\mathrm{pH} 8.2$ with results expressed as malic acid equivalents.

5. The extracted juice was also used for measurement of soluble solids concentration (SSC) using a refractometer (Atago PR-100; Atago Co. Ltd., Tokyo, Japan) with, results expressed as equivalent to percent SSC at $20^{\circ} \mathrm{C}$.

6. The Streif index was calculated as [firmness (SSC $\times$ starch hydrolysis score $\left.)^{-1}\right]$ (Streif, 1996). 
7. Internal ethylene production: $3 \mathrm{~h}$ after harvesting, the two fruit were placed in 0.5 -L jars at $20^{\circ} \mathrm{C}$. The jars were sealed for 3 to $4 \mathrm{~h}$ before measurements. Ethylene was quantified by gas chromatography (Agilent GC 6850) equipped with a flame ionization detector, automatic gas sampling valve $1000 \mu \mathrm{L}$, $150{ }^{\circ} \mathrm{C}$, and fitted with a capillary column HP plot Q $30 \times 0.53 \mathrm{~mm} \times$ $40 \mu \mathrm{m}$ (Agilent). Analyses were run isothermally with an oven temperature of $70{ }^{\circ} \mathrm{C}$ and a detector temperature of $250{ }^{\circ} \mathrm{C}$. Flow rates for nitrogen, hydrogen, and compressed air were 20, 45, and $225 \mathrm{~mL} \cdot \mathrm{min}^{-1}$. Ethylene was quantified by peak area, and external standards were used for calibration. Evaluation and calculation were carried out with Chemstation Version 9.03 (Agilent).

Analysis of quality parameters at harvest. In all experiments, quality parameters, skin color, flesh firmness, SSC, and TA were estimated on two fruits per tree at harvest (eight fruits per block and treatment in Expt. 1 and 10 fruits per block in the other three experiments) as described previously. In addition, the following analyses were conducted only in Expt. 1 on another two fruits per tree:

1. Total anthocyanins were determined by $\mathrm{pH}$-differential spectrophotometry (Wrolstad, 1993) using a Cary 50 Bio spectrophotometer (Varian Inc., Australia). For extraction of anthocyanins, $1.00 \mathrm{~g}$ of powdered lyophilized apple flesh was added to $20 \mathrm{~mL} 70 \%$ ethanol with $10 \mathrm{~mm} \mathrm{HCl}$ in a $50-\mathrm{mL}$ plastic tube and placed in a ultrasonic bath (Bandelin Sonorex, $35 \mathrm{kHz}$ ) for $15 \mathrm{~min}$ followed by extraction overnight, in dark, at $4{ }^{\circ} \mathrm{C}$ on an orbital shaker (Forma Sci, Canada). Two samples of this extract, each $1000 \mu \mathrm{L}$, were placed into two different $10-\mathrm{mL}$ volumetric flasks and diluted to volume with buffers at $\mathrm{pH}$ 1.0 and $\mathrm{pH} 4.5$, respectively. The absorbance was measured at wavelength $510 \mathrm{~nm}$ using the molar absorptivity for cyanidin-3-glycoside (26900 $\left.\mathrm{L} \cdot \mathrm{mol}^{-1} \cdot \mathrm{cm}^{-1}\right)$. Content of total anthocyanins was calculated according to Wrolstad (1993) and results expressed as $\mathrm{mg} \cdot \mathrm{kg}^{-1}$ dry weight.

2. Total phenolics were determined with the Folin-Ciocalteau method as modified by Dewanto et al. (2002). One gram of lyophilized and milled apple flesh was extracted in $20 \mathrm{~mL} 70 \%$ ethanol overnight on an orbital shaker (Forma Sci) at $4{ }^{\circ} \mathrm{C}$. Fifty microliters of this extract, $100 \mu \mathrm{L}$ high-purity water, 18.2 M $\Omega$ (Millipore Simplicity, France), and $100 \mu \mathrm{L}$ Folin-Ciocalteau phenol reagent (BDH, U.K.) were added into a cuvette, mixed, and held for $6 \mathrm{~min}$ at room temperature. A volume of $1000 \mu \mathrm{L}$ of $0.66 \mathrm{M} \mathrm{Na} \mathrm{NaO}_{3}$ was added and

A
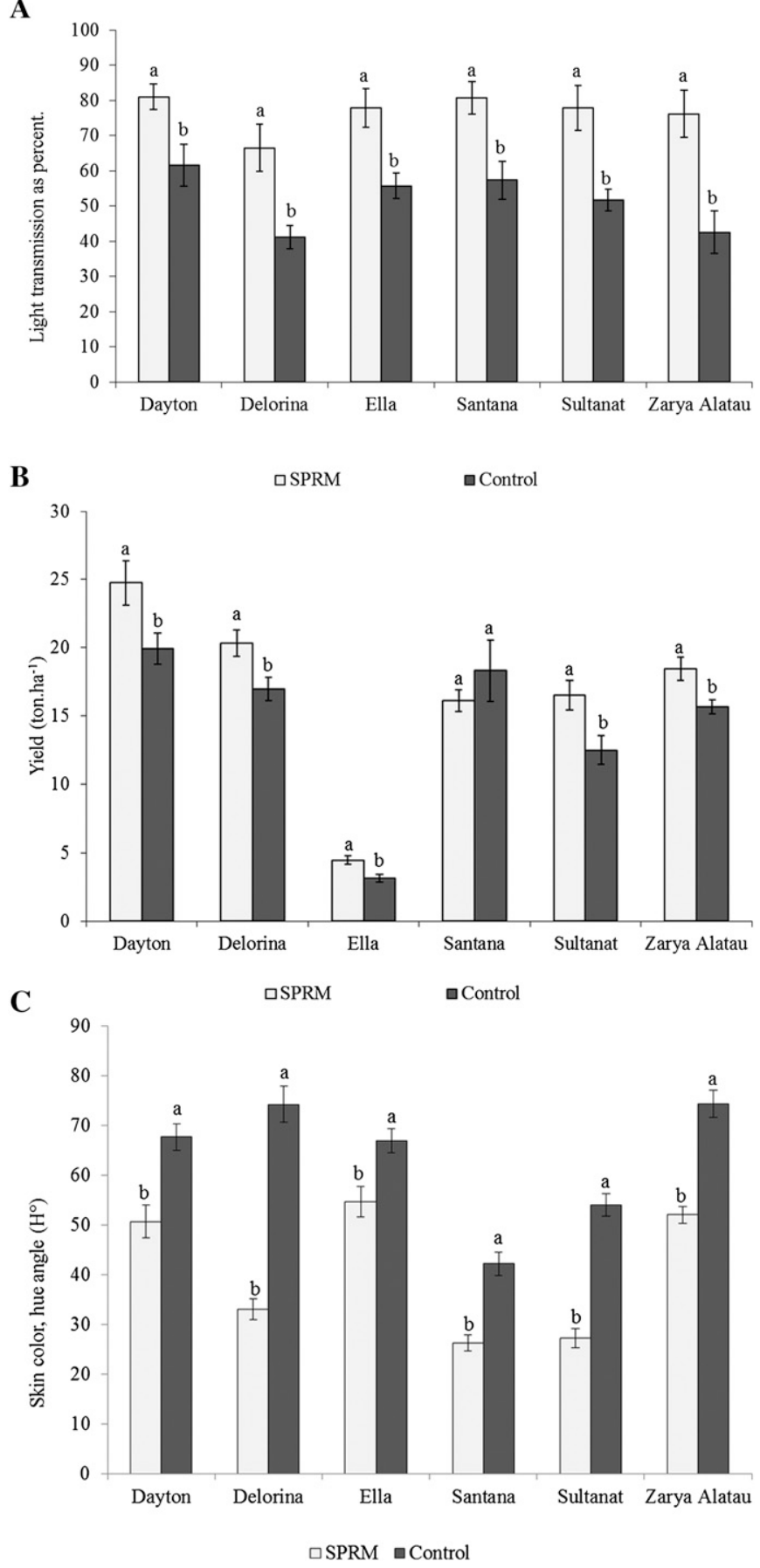

Fig. 1. (A) Effect of SPRM (summer pruning in July and covering orchard floor by reflective mulch) on the light transmission (values are means of two years, three replicates of six measurements each). Within each cultivar, bars with the same letter are not statistically different at $P \leq 0.001$. A significant interaction $(P \leq 0.05)$ between the effects of season and management model for light transmission could not be found in any cultivar. (B) Effect of SPRM (summer pruning in July and covering orchard floor by reflective mulch) on the cumulative yield during three years (values are means of three replicates of four trees each). Within each cultivar, bars with the same letter are not statistically different at $P \leq 0.001$. A significant interaction $(P \leq 0.05)$ between the effects of season and management model for light transmission could not be found in any cultivar. Tree age was nine years at start. (C) Effect of SPRM (summer pruning in July and covering orchard floor by reflective mulch) on fruit color (values are means of three years, three replicates of four trees and eight fruits each). Within each cultivar, bars with the same letter are not statistically different at $P \leq 0.001$. A significant interaction $(P \leq 0.05)$ between the effects of season and management model for fruit color could not be found in any cultivar. Fruit color expressed as hue angle, $\mathrm{H}^{\circ}$.

the mixture held for $75 \mathrm{~min}$ at room temperature. The absorbance was measured at $765 \mathrm{~nm}$ using a Cary 50 Bio spectrophotometer (Varian Inc.). Content of total phenolics was calculated from a standard curve of gallic acid, $(3,4,5-$ trihydroxybenzoic acid) (Sigma-Aldrich, Germany) and results expressed as 
gallic acid equivalents on a dry weight basis, $\mathrm{g} \cdot \mathrm{kg}^{-1}$.

3. Contents of vitamin $\mathrm{C}$, ascorbic acid, and dehydroascorbic acid were determined in apple flesh. Analyses were performed under dim green light. A total of $4 \mathrm{~g}$ apple flesh was placed in a plastic bottle together with $20 \mathrm{~mL}$ of meta-phosphoric acid (1.5\%) and homogenized with an Ultra Turrax apparatus (Model TP1810; IKA Werke $\mathrm{GmbH}$, Staufen, Germany) for $1 \mathrm{~min}$. Samples were stored in the freezer (Labconco 77545; Mezory) at $-80{ }^{\circ} \mathrm{C}$ before high-performance liquid chromatography (HPLC) analysis. Before HPLC analysis, the samples were thawed in lukewarm water and centrifuged for $8 \mathrm{~min}$ at $12,900 \mathrm{~g}$, after which $5 \mathrm{~mL}$ of each supernatant was filtered through a Sep-pak Plus C18 cartridge (Waters, Milford, MA) previously conditioned with $5 \mathrm{~mL}$ of methanol and $10 \mathrm{~mL}$ of water. The first $4 \mathrm{~mL}$ of each sample was discarded, and the remaining $1 \mathrm{~mL}$ was collected in a microcentrifuge. An aliquot of the collected extract was used for HPLC analysis, as described below. The dehydroascorbic acid concentration was calculated by subtracting the ascorbic acid concentration from the total vitamin $\mathrm{C}$ concentration obtained after a reduction procedure. For this procedure, an aliquot of the extract was added to a $1 \%$ dithiothreitol solution and allowed to react for $30 \mathrm{~min}$ at $\mathrm{pH}$ 7.0, where the $\mathrm{pH}$ was adjusted with $\mathrm{K}_{2} \mathrm{HPO}_{4} 1 \mathrm{M}$ before HPLC analysis. Samples were analyzed on an Agilent 1100 series (Agilent Technologies, Waldbronn, Germany) HPLC using an isocratic gradient with a flow rate of $1.2 \mathrm{~mL} \cdot \mathrm{min}^{-1}$. The mobile phase consisted of $25 \% \mathrm{NH}_{4} \mathrm{H}_{2} \mathrm{PO}_{4}(15 \mathrm{~mm})$ and $75 \%$ acetonitrile with the $\mathrm{pH}$ adjusted to 3.9. A $20-\mu \mathrm{L}$ portion was injected from each sample. A Waters carbohydrate analysis column, $300 \times 3.9 \mathrm{~mm}$ with a particle size of $10 \mu \mathrm{m}$, was used. Absorbance was measured at $248 \mathrm{~nm}$ using a photodiode array detector. Samples were quantified using an external ascorbic acid standard (Merck, Darmstadt, Germany) with $98 \%$ recovery. The concentrations were expressed as vitamin $\mathrm{C}$ on a dry weight basis, $\mathrm{mg} \cdot \mathrm{kg}^{-1}$.

Analysis of fruit storage potential. Fruit storage potential was estimated according to the maintenance of quality and the occurrence of physiological disorders (soft scald, flesh browning, and internal breakdown) and storage rots (bitter rot, Colletotrichum spp., and bull's eye rot, Neofabraea spp.) during storage. Because fruit may develop an undesirable "mealy" texture when kept at room temperature for daily home consumption or by small-scale distributors and retailers (Varela et al., 2005), fruit quality must be properly assessed after keeping at ambient

Table 1. Effect of SPRM (summer pruning and covering the orchard floor with reflective mulch) on fruit quality and storage life of six apple cultivars grown in an organic orchard and stored in air for four months. ${ }^{\mathrm{z}}$

\begin{tabular}{llcccc}
\hline Cultivar & Management model & Firmness $\left(\mathrm{kg} \cdot \mathrm{cm}^{-2}\right)$ & SSC $(\%)^{\mathrm{x}}$ & $\mathrm{TA}\left(\mathrm{g} \cdot \mathrm{mL}^{-1}\right)^{\mathrm{x}}$ & Decay (\%) \\
\hline Dayton & SPRM & $5.5 \mathrm{~b}^{\mathrm{y}}$ & $11.6 \mathrm{a}$ & $0.66 \mathrm{~b}$ & $0.0 \mathrm{~b}$ \\
& Standard & $4.9 \mathrm{a}$ & $11.1 \mathrm{a}$ & $0.58 \mathrm{a}$ & $3.0 \mathrm{a}$ \\
\multirow{2}{*}{ Delorina } & SPRM & $6.7 \mathrm{a}$ & $8.3 \mathrm{~b}$ & $0.60 \mathrm{~b}$ & $0.8 \mathrm{~b}$ \\
& Standard & $6.5 \mathrm{a}$ & $6.4 \mathrm{a}$ & $0.53 \mathrm{a}$ & $6.3 \mathrm{a}$ \\
\multirow{2}{*}{ Ella } & SPRM & $8.3 \mathrm{a}$ & $8.7 \mathrm{a}$ & $0.37 \mathrm{~b}$ & $5.6 \mathrm{a}$ \\
& Standard & $8.2 \mathrm{a}$ & $9.5 \mathrm{a}$ & $0.25 \mathrm{a}$ & $6.8 \mathrm{a}$ \\
\multirow{2}{*}{ Santana } & SPRM & $7.1 \mathrm{a}$ & $10.3 \mathrm{a}$ & $0.58 \mathrm{~b}$ & $0.5 \mathrm{~b}$ \\
\multirow{2}{*}{ Sultanat } & Standard & $7.3 \mathrm{a}$ & $10.8 \mathrm{a}$ & $0.47 \mathrm{a}$ & $2.8 \mathrm{a}$ \\
\multirow{2}{*}{ Zarya Alatau } & SPRM & $5.8 \mathrm{~b}$ & $11.2 \mathrm{~b}$ & $0.39 \mathrm{~b}$ & $2.5 \mathrm{~b}$ \\
& Standard & $5.2 \mathrm{a}$ & $10.4 \mathrm{a}$ & $0.31 \mathrm{a}$ & $3.2 \mathrm{a}$ \\
& SPRM & $6.9 \mathrm{~b}$ & $10.9 \mathrm{a}$ & $0.60 \mathrm{a}$ & $0.3 \mathrm{~b}$ \\
& Standard & $5.5 \mathrm{a}$ & $10.5 \mathrm{a}$ & $0.60 \mathrm{a}$ & $2.7 \mathrm{a}$
\end{tabular}

\begin{tabular}{lcccc} 
& \multicolumn{2}{c}{ Year $\times$ management model interaction } & NS & NS \\
Dayton & NS & NS & $*$ & NS \\
Delorina & NS & NS & $*$ & $*$ \\
Ella & NS & NS & NS & NS \\
Santana & NS & NS & NS & NS \\
Sultanat & NS & NS & $*$ & NS Alatau \\
Zarya A
\end{tabular}

${ }^{\mathrm{z}}$ Values are means of three years with three replicates.

${ }^{y}$ Values for each cultivar/column with the same letter are not statistically different at $P \leq 0.001$.

${ }^{\mathrm{x}} \mathrm{SSC}=$ soluble solid concentration; TA $=$ titratable acid expressed as malic acid.

Ns and $*=$ nonsignificant or significant differences at $P \leq 0.05$, respectively.

Table 2. Effects of SPRM (summer pruning and covering the orchard floor with reflective mulch) on antioxidant contents (anthocyanins, total phenolics, and ascorbic acid) at harvest in six apple cultivars grown in an organic orchard. ${ }^{\mathrm{z}}$

\begin{tabular}{llccc}
\hline Cultivars & $\begin{array}{c}\text { Management } \\
\text { model }\end{array}$ & $\begin{array}{c}\text { Anthocyanin } \\
\left(\mathrm{mg} \cdot \mathrm{kg}^{-1} \mathrm{dw}^{\mathrm{x}}\right)\end{array}$ & $\begin{array}{c}\text { Total phenolic } \\
\left(\text { content } \mathrm{g} \cdot \mathrm{kg}^{-1} \mathrm{dw}\right)\end{array}$ & $\begin{array}{c}\text { Ascorbic acid } \\
\left(\mathrm{mg} \cdot \mathrm{kg}^{-1} \mathrm{dw}\right)\end{array}$ \\
\hline Dayton & SPRM & $56.4 \mathrm{a}^{\mathrm{y}}$ & $7.88 \mathrm{a}$ & $298.2 \mathrm{a}$ \\
& Standard & $14.1 \mathrm{~b}$ & $6.31 \mathrm{~b}$ & $311.1 \mathrm{a}$ \\
Delorina & SPRM & $40.7 \mathrm{a}$ & $4.96 \mathrm{a}$ & $263.7 \mathrm{a}$ \\
Ella & Standard & $18.0 \mathrm{~b}$ & $4.21 \mathrm{a}$ & $231.1 \mathrm{~b}$ \\
& SPRM & $37.8 \mathrm{a}$ & $6.74 \mathrm{a}$ & $227.1 \mathrm{a}$ \\
Santana & Standard & $19.5 \mathrm{~b}$ & $4.84 \mathrm{~b}$ & $198.2 \mathrm{~b}$ \\
\multirow{2}{*}{ Sultanat } & SPRM & $116.4 \mathrm{a}$ & $3.71 \mathrm{a}$ & $242.9 \mathrm{a}$ \\
& Standard & $53.6 \mathrm{~b}$ & $3.20 \mathrm{a}$ & $215.1 \mathrm{~b}$ \\
Zarya Alatau & SPRM & $115.3 \mathrm{a}$ & $6.52 \mathrm{a}$ & $410.9 \mathrm{a}$ \\
& Standard & $83.1 \mathrm{~b}$ & $5.09 \mathrm{~b}$ & $417.0 \mathrm{a}$ \\
& SPRM & $47.6 \mathrm{a}$ & $4.76 \mathrm{a}$ & $362.7 \mathrm{a}$ \\
& Standard & $5.4 \mathrm{~b}$ & $3.70 \mathrm{~b}$ & $376.7 \mathrm{a}$
\end{tabular}

Year $\times$ management model interaction

Dayton NS N $\quad$ N** NS

Delorina NS NS NS

Ella $\quad$ NS $\quad$ NS

$\begin{array}{lccc}\text { Santana } & \text { NS } & \text { NS } & \text { NS } \\ \text { Sultanat } & \text { NS } & * & \text { NS }\end{array}$

Zarya Alatau

NS NS

${ }^{2}$ Values are means of three years with three replicates of 40 fruits each.

${ }^{y}$ Values for each cultivar/column with the same letter are not statistically different at $P \leq 0.001$.

${ }^{\mathrm{x}}$ Dry weight.

NS, ${ }^{*}$, and $* * *=$ nonsignificant or significant differences at $P \leq 0.05$ or 0.001 , respectively.

conditions (room temperature). Therefore, in all experiments, fruits were held after storage in a plastic chamber at $18 \pm 2{ }^{\circ} \mathrm{C}$ and $80 \% \mathrm{RH}$ for 1 week (shelf life) before evaluation of quality and storage potential. Quality parameters were determined as done at harvest, and disorders and decay were determined according to Sandskär (2005) and estimated as percentage damaged fruit.

Statistical analyses. Data were subjected to arsine and square root transformation before analyses of variance (ANOVA) to improve normality of data. For Expt. 1, all data were analyzed with a mixed-model
ANOVA with years (2008 to 2010), treatments (management with pruning and groundcover and standard practice, respectively) and their interactions as fixed effects for light transmission, yield, fruit quality parameters at harvest and after storage, anthocyanin content, total phenolic concentration, ascorbic acid content, and storage decay. For Expt. 2, treatments were replaced with harvesting date (4 weeks of harvesting) in a mixed-model ANOVA. Pearson correlation coefficients were calculated to reveal the relationship between harvesting date and changes in maturity indices. For Expt. 3, data were analyzed with 
a one-way ANOVA followed by Tukey's Studentized range test. For Expt. 4, treatments were replaced by storage methods (air, CA, ULO) in a mixed-model ANOVA. Least significant difference values $(P \leq 0.05,0.01$, and 0.001 ) were calculated for comparison of means. All analyses were carried out with the SAS statistical program package (SAS Inst. Inc., Cary, NC).

\section{Results}

Expt. 1: Effects of summer pruning and reflective mulch. The summer pruning and reflective mulch (SPRM) management model increased light transmission in the trees $(P \leq$ 0.001 ) of all six cultivars (Fig. 1A). There was no significant interaction between the effects of year and management in any of the cultivars. SPRM increased the cumulative yield over the three years in five of the cultivars ( $P \leq 0.001$; Fig. 1B), and improved skin coloration in all of them $(P \leq 0.001$; Fig. $1 C)$. The other quality parameters evaluated at harvest such as fruit weight, firmness, SSC, and TA were not significantly affected by the management practices.

When analyzed after storage and shelf life, SPRM produced less fruit softening in 'Dayton', 'Sultanat', and 'Zarya Alatau' ( $10 \%$ to $15 \%)$; less TA decline in all cultivars except 'Zarya Alatau' ( $8 \%$ to $16 \%$ ); and a better SSC development in three cultivars, 'Delorina', 'Sultanat', and 'Zarya Alatau' (5\% to $17 \%$ ), when compared with fruits grown with the standard management $(P \leq 0.001$; Table 1). Neofabraea spp. was the most common pathogen, causing $3.0 \%$ to $7.0 \%$ damage. Fruit from trees in the applied management showed less damage $(P \leq 0.001)$ from this pathogen in all cultivars except 'Ella' (Table 1). These fruits also had a higher anthocyanin content in all cultivars $(P \leq$ 0.001 ; Table 2), a higher total phenolic content $(25 \%, 28 \%, 29 \%$, and $39 \%$ in 'Dayton', 'Sultanat', 'Zarya Alatau', and 'Ella', respectively), and a $13 \%$ to $15 \%$ higher ascorbic acid content in 'Delorina', 'Ella', and 'Santana' $(P \leq 0.001$; Table 2). Significant interactions between year and management were not found in any of the cultivars for anthocyanin or ascorbic acid and only in 'Delorina' ( $P \leq$ $0.001)$ and 'Sultanat' $(P \leq 0.05)$ for total phenolics (Table 2).

Expt. 2: Determination of optimal harvest date. In all three years, ethylene production increased during the selected 4 weeks around the optimal harvest date, and the cultivars were well differentiated. Earlyripening cultivars showed a faster increasing ethylene production in comparison with fallor late-ripening cultivars. When calculated as weekly averages (three picking times a week), the autocatalytic ethylene production remained at a threshold of $0.1 \mu \mathrm{L} \cdot \mathrm{L}^{-1} \cdot \mathrm{kg}^{-1} \cdot \mathrm{h}^{-1}$ for 1 week in 'Agra', 'Eir', and 'Ella' and for 2 weeks in the other five cultivars $(P \leq 0.001$; Table 3). A significant increase in internal ethylene production (IEC) occurred in the third harvesting week in 'Agra', 'Eir', 'Ella', and 'Delorina' and in the fourth harvesting

Table 3. Changes in three harvesting parameters during maturation for eight apple cultivars grown in an organic orchard. ${ }^{z}$

\begin{tabular}{|c|c|c|c|c|}
\hline Cultivar & $\begin{array}{l}\text { Harvest week } \\
(\text { DAFB })^{\mathrm{x}}\end{array}$ & $\begin{array}{l}\text { Internal ethylene production } \\
\qquad\left(\mu \mathrm{L} \cdot \mathrm{L}^{-1} \cdot \mathrm{kg}^{-1} \cdot \mathrm{h}^{-1}\right)\end{array}$ & $\operatorname{Starch}(1-10)^{\mathrm{w}}$ & Streif index ${ }^{\mathrm{w}}$ \\
\hline \multirow[t]{4}{*}{ Agra } & $95-101$ & $0.1 \mathrm{c}^{\mathrm{y}}$ & $4.7 \mathrm{c}$ & $0.19 \mathrm{a}$ \\
\hline & $102-108$ & $0.5 \mathrm{c}$ & $6.1 \mathrm{~b}$ & $0.11 \mathrm{~b}$ \\
\hline & $109-115$ & $7.8 \mathrm{~b}$ & $6.9 \mathrm{~b}$ & $0.08 \mathrm{bc}$ \\
\hline & $116-122$ & $18.4 \mathrm{a}$ & $9.6 \mathrm{a}$ & $0.05 \mathrm{c}$ \\
\hline \multirow[t]{4}{*}{ Eir } & $100-106$ & $0.1 \mathrm{c}$ & $3.3 \mathrm{c}$ & $0.27 \mathrm{a}$ \\
\hline & $107-113$ & $0.8 \mathrm{c}$ & $4.5 \mathrm{~b}$ & $0.15 \mathrm{~b}$ \\
\hline & $114-120$ & $3.4 \mathrm{~b}$ & $6.0 \mathrm{a}$ & $0.13 \mathrm{~b}$ \\
\hline & $121-127$ & $5.3 \mathrm{a}$ & $6.7 \mathrm{a}$ & $0.09 \mathrm{c}$ \\
\hline \multirow[t]{4}{*}{ Ella } & $105-111$ & $0.1 \mathrm{c}$ & $3.2 \mathrm{c}$ & $0.28 \mathrm{a}$ \\
\hline & $112-118$ & $0.4 \mathrm{c}$ & $4.4 \mathrm{~b}$ & $0.20 \mathrm{~b}$ \\
\hline & $119-125$ & $0.8 \mathrm{~b}$ & $5.0 \mathrm{~b}$ & $0.16 \mathrm{~b}$ \\
\hline & $126-132$ & $3.5 \mathrm{a}$ & $7.0 \mathrm{a}$ & $0.09 \mathrm{c}$ \\
\hline \multirow[t]{4}{*}{ Dayton } & $120-126$ & $0.0 \mathrm{~b}$ & $3.1 \mathrm{~b}$ & $0.27 \mathrm{a}$ \\
\hline & $127-133$ & $0.0 \mathrm{~b}$ & $3.3 \mathrm{~b}$ & $0.22 \mathrm{ab}$ \\
\hline & $134-140$ & $0.3 \mathrm{~b}$ & $3.6 \mathrm{~b}$ & $0.19 \mathrm{~b}$ \\
\hline & $141-147$ & $2.5 \mathrm{a}$ & $5.8 \mathrm{a}$ & $0.10 \mathrm{c}$ \\
\hline \multirow[t]{4}{*}{ Delorina } & $125-131$ & $0.1 \mathrm{c}$ & $3.2 \mathrm{c}$ & $0.32 \mathrm{a}$ \\
\hline & $132-138$ & $0.1 \mathrm{c}$ & $4.1 \mathrm{c}$ & $0.25 \mathrm{~b}$ \\
\hline & $139-145$ & $0.9 \mathrm{~b}$ & $5.0 \mathrm{~b}$ & $0.19 \mathrm{~b}$ \\
\hline & $146-152$ & $2.1 \mathrm{a}$ & $6.4 \mathrm{a}$ & $0.11 \mathrm{c}$ \\
\hline \multirow[t]{4}{*}{ Santana } & $120-126$ & $0.1 \mathrm{~b}$ & $2.4 \mathrm{~b}$ & $0.34 \mathrm{a}$ \\
\hline & $127-133$ & $0.1 \mathrm{~b}$ & $3.6 \mathrm{~b}$ & $0.22 \mathrm{~b}$ \\
\hline & $134-140$ & $0.6 \mathrm{~b}$ & $4.0 \mathrm{~b}$ & $0.18 \mathrm{~b}$ \\
\hline & $141-147$ & $3.5 \mathrm{a}$ & $5.4 \mathrm{a}$ & $0.11 \mathrm{c}$ \\
\hline \multirow[t]{4}{*}{ Sultanat } & $125-131$ & $0.0 \mathrm{~b}$ & $2.9 \mathrm{~b}$ & $0.37 \mathrm{a}$ \\
\hline & $132-138$ & $0.1 \mathrm{~b}$ & $3.7 \mathrm{~b}$ & $0.28 \mathrm{~b}$ \\
\hline & $139-145$ & $0.6 \mathrm{~b}$ & $4.7 \mathrm{~b}$ & $0.20 \mathrm{~b}$ \\
\hline & $146-152$ & $3.4 \mathrm{a}$ & $6.9 \mathrm{a}$ & $0.11 \mathrm{c}$ \\
\hline Zarya & $120-126$ & $0.1 \mathrm{~b}$ & $3.1 \mathrm{~b}$ & $0.35 \mathrm{a}$ \\
\hline \multirow[t]{3}{*}{ Alatau } & $127-133$ & $0.1 \mathrm{~b}$ & $4.2 \mathrm{~b}$ & $0.20 \mathrm{~b}$ \\
\hline & $134-140$ & $1.5 \mathrm{~b}$ & $5.0 \mathrm{~b}$ & $0.15 \mathrm{~b}$ \\
\hline & $141-147$ & $4.4 \mathrm{a}$ & $7.0 \mathrm{a}$ & $0.09 \mathrm{c}$ \\
\hline
\end{tabular}

Agra

Eir

Ella
Dayton

Delorina

Santana

Sultanat

Year $\times$ harvesting date interaction

Zarya Alatau

NS

*

NS

NS

$\mathrm{NS}$
$*$

NS

***

\begin{tabular}{cc} 
NS & NS \\
$* * *$ & $* *$ \\
$\mathrm{NS}$ & $\mathrm{NS}$ \\
$\mathrm{NS}$ & $\mathrm{NS}$ \\
$*$ & $* * *$ \\
$\mathrm{NS}$ & $*$ \\
$* * *$ & $* * *$ \\
$\mathrm{NS}$ & $\mathrm{NS}$ \\
\hline
\end{tabular}

${ }^{z}$ Values are means of three years, three pickings a week, and three replicates of five trees each.

${ }^{y}$ Values for each cultivar/column with the same letter are not statistically different at $P \leq 0.001$.

'Days after full bloom.

${ }^{\mathrm{w}}$ Starch $(1-10)=$ starch conversion score; Streif index $=$ firmness $(\mathrm{SSC} \times \operatorname{starch} \text { conversion score })^{-1}$. $\mathrm{NS}, *, * *$, and $* * *=$ nonsignificant or significant differences at $P \leq 0.05,0.01$, or 0.001 , respectively.

week in 'Dayton', 'Santana', 'Sultanat', and 'Zarya Alatau' ( $P \leq 0.001$; Table 3$)$. This rapid change took place toward the end of the critical week in 2008 and 2010 but 5 d earlier in 2009. Interaction between the effects of year and harvesting week for IEC was found only in two cultivars $(P \leq 0.05)$ : the earlyripening 'Eir' and the late-ripening 'Sultanat' (Table 3).

A significant change in starch hydrolysis, calculated as weekly averages (three picking times a week), occurred in the last week of the harvesting period for 'Dayton', 'Santana', and 'Sultanat' ( $P \leq 0.001$; Table 3). In 'Zarya Alatau' and the more early-ripening cultivars ('Agra', 'Eir', and 'Ella'), starch hydrolysis showed two peaks, one in the second week and another in the last week of the harvesting period ( $P \leq 0.001$; Table 3$)$. Interaction between year and harvesting week for starch hydrolysis was found in 'Eir' $(P \leq 0.001)$, 'Delorina' $(P \leq 0.05)$, and 'Sultanat' $(P \leq 0.001)$; in 2009 , the major change in starch index occurred $5 \mathrm{~d}$ earlier than in 2008 and 2010.

Fruit firmness decreased during the harvesting period, and in all three years, maximum reduction occurred in the last week in conjunction with or particularly after the significant rise in IEC and starch hydrolysis $(P \leq 0.001$; Table 4). An interaction between harvesting date and season was found in 'Eir' $(P \leq 0.01)$ and 'Sultanat' $(P \leq 0.001)$. SSC increased significantly during the harvesting period in all cultivars except 'Zarya Alatau'. This increase took place during 1 week for 'Agra', 'Ella', 'Dayton', 'Delorina', and 'Sultanat' and during 2 weeks for 'Eir' and 'Santana', regardless of the production year $(P \leq 0.001$; Table 4). Again, a significant $(P \leq 0.01)$ interaction was noted only for 'Eir' and 'Sultanat'. Reduction in TA was most pronounced in the second week ('Agra', 'Ella', 'Santana', 'Sultanat', and 'Zarya Alatau') or 
the third week ('Eir', 'Dayton', and 'Delorina') $(P \leq 0.001)$, again with interaction effects for 'Eir' $(P \leq 0.05)$ and 'Sultanat' $(P<0.000)$. The Streif index decreased in the first and last weeks of the harvesting period and remained steady in the 2 intermediate weeks for all cultivars $(P \leq 0.001$; Table 4$)$. A significant interaction between harvesting date and season for Streif index was found in 'Eir' $(P \leq 0.01)$, 'Delorina', and 'Sultanat' (both $P \leq 0.001$ ).

Occurrence of fruit decay during storage in air as well as maintenance of fruit quality is associated with ethylene production. In all three years, fruit picked after a significant increase in IEC showed higher decay in comparison with fruit picked before this increase $(P \leq 0.001)$, except for the cultivar Dayton (Fig. 2). Firmness, SSC, and TA of fruit, picked before the IEC increase, also remained more stable compared with fruits picked 2 weeks before or after this increase $(P \leq 0.001$; Table 5). An interaction between the effects of season and harvesting date was found in 'Eir' and 'Sultanat' for softening, SSC development, and TA decline and in 'Agra', 'Ella', 'Delorina', and 'Zarya Alatau' for storage decay $(P \leq 0.05)$.

Ethylene production was positively correlated with starch hydrolysis and the Streif index during ripening in all eight cultivars, and negatively correlated with fruit firmness and TA (Table 6). Correlations between ethylene production and SSC were significant in 'Eir', 'Agra', 'Santana', 'Zarya Alatau', and 'Dayton'. All these correlations were found in each of the three years.

Expt. 3: Post-harvest treatment with heating and ethanol. Dipping fruit in hot water $\left(46^{\circ} \mathrm{C}\right.$ for $\left.120 \mathrm{~s}\right)$ decreased decay caused by Colletotrichum and Neofabraea during storage $(P \leq 0.001)$ in two cultivars, Dayton and Eir, whereas no effect was detected on fruit of 'Agra' and 'Sultanat' (Fig. 3). Post-harvest spraying fruits with $10 \%$ ethanol was even more efficient and decreased the incidence of storage decay $(P \leq 0.001)$ in 'Dayton', 'Sultanat', 'Eir', and 'Agra' (Fig. 3). This positive effect was found in both years, and there was no significant interaction between year and treatment for any of the cultivars.

Expt. 4: Storage methods. CA storage (2.0 $\mathrm{O}_{2} \mathrm{kPa}$ and $2.0 \mathrm{kPa} \mathrm{CO}_{2}$ ) had a positive effect on fruit firmness and TA in all of the studied cultivars $(P \leq 0.001)$ except 'Eir' (Table 7). By contrast, SSC showed a positive response to CA only in 'Agra' and 'Dayton' $(P \leq 0.001$; Table 7). Because no storage disorders (except flesh browning in ULO 2 for 'Delorina' and 'Zarya Alatau') were noted during the three seasons, storage decay was restricted to fungal decay caused by Colletotrichum and Neofabraea. The amount of storage decay decreased as a result of CA storage in all cultivars in comparison with storage in air $(P \leq 0.001$; Table 7). The positive effect of $\mathrm{CA}$ on fruit storability was found in all three years despite significant interactions between storage method and year in 'Eir' and 'Dayton' $(P \leq 0.01)$ and in 'Delorina' and 'Sultanat' $(P \leq 0.001)$.
Table 4. Development of fruit quality during maturation, evaluated as firmness, soluble solids content (SSC), titratable acid (TA), and hue angle $\left(\mathrm{H}^{\circ}\right.$; skin color) for eight apple cultivars grown in an organic orchard. ${ }^{\mathrm{z}}$

\begin{tabular}{|c|c|c|c|c|c|}
\hline Cultivar & Harvest week (DAFB) ${ }^{\mathrm{x}}$ & Firmness $\left(\mathrm{kg} \cdot \mathrm{cm}^{-2}\right)$ & $\mathrm{SSC}(\%)^{\mathrm{w}}$ & $\mathrm{TA}\left(\mathrm{g} \cdot \mathrm{mL}^{-1}\right)^{\mathrm{w}}$ & Color $\left(\mathrm{H}^{\circ} \text { value }\right)^{\mathrm{w}}$ \\
\hline \multirow[t]{4}{*}{$\overline{\text { Agra }}$} & $95-101$ & $8.8 \mathrm{a}^{\mathrm{y}}$ & $10.3 \mathrm{~b}$ & $0.74 \mathrm{a}$ & $44.1 \mathrm{a}$ \\
\hline & $102-108$ & $7.3 \mathrm{~b}$ & $11.2 \mathrm{a}$ & $0.58 \mathrm{~b}$ & $28.4 \mathrm{~b}$ \\
\hline & $109-115$ & $6.6 \mathrm{~b}$ & $11.9 \mathrm{a}$ & $0.38 \mathrm{c}$ & $26.7 \mathrm{~b}$ \\
\hline & $116-122$ & $5.5 \mathrm{c}$ & $11.9 \mathrm{a}$ & $0.27 \mathrm{c}$ & $25.9 \mathrm{~b}$ \\
\hline \multirow[t]{4}{*}{ Eir } & $100-106$ & $8.4 \mathrm{a}$ & $10.2 \mathrm{c}$ & $0.79 \mathrm{a}$ & $48.6 \mathrm{a}$ \\
\hline & $107-113$ & $7.5 \mathrm{~b}$ & $10.3 \mathrm{c}$ & $0.68 \mathrm{a}$ & $28.8 \mathrm{~b}$ \\
\hline & $114-120$ & $7.2 \mathrm{~b}$ & $10.9 \mathrm{~b}$ & $0.51 \mathrm{~b}$ & $24.6 \mathrm{c}$ \\
\hline & $121-127$ & $6.2 \mathrm{c}$ & $11.4 \mathrm{a}$ & $0.29 \mathrm{c}$ & $21.9 \mathrm{c}$ \\
\hline \multirow[t]{4}{*}{ Ella } & $105-111$ & $9.1 \mathrm{a}$ & $10.0 \mathrm{c}$ & $1.04 \mathrm{a}$ & $81.4 \mathrm{a}$ \\
\hline & $112-118$ & $8.9 \mathrm{a}$ & $10.4 \mathrm{~b}$ & $0.82 \mathrm{~b}$ & $66.8 \mathrm{~b}$ \\
\hline & $119-125$ & $8.1 \mathrm{~b}$ & $10.8 \mathrm{a}$ & $0.64 \mathrm{c}$ & $36.0 \mathrm{c}$ \\
\hline & $126-132$ & $7.0 \mathrm{c}$ & $10.6 \mathrm{ab}$ & $0.34 \mathrm{~d}$ & $26.7 \mathrm{~d}$ \\
\hline \multirow[t]{4}{*}{ Dayton } & $120-126$ & $8.4 \mathrm{a}$ & $11.1 \mathrm{c}$ & $0.90 \mathrm{a}$ & $72.6 \mathrm{a}$ \\
\hline & $127-133$ & $8.1 \mathrm{a}$ & $11.8 \mathrm{ab}$ & $0.79 \mathrm{ab}$ & $67.7 \mathrm{a}$ \\
\hline & $134-140$ & $7.8 \mathrm{a}$ & $11.6 \mathrm{bc}$ & $0.66 \mathrm{~b}$ & $39.1 \mathrm{~b}$ \\
\hline & $141-147$ & $6.8 \mathrm{~b}$ & $12.3 \mathrm{a}$ & $0.39 \mathrm{c}$ & $23.3 \mathrm{c}$ \\
\hline \multirow[t]{4}{*}{ Delorina } & $125-131$ & $10.3 \mathrm{a}$ & $10.0 \mathrm{~b}$ & $0.86 \mathrm{a}$ & $82.3 \mathrm{a}$ \\
\hline & $132-138$ & $9.6 \mathrm{~b}$ & $10.5 \mathrm{a}$ & $0.80 \mathrm{a}$ & $74.2 \mathrm{a}$ \\
\hline & $139-145$ & $9.2 \mathrm{~b}$ & $10.6 \mathrm{a}$ & $0.62 \mathrm{~b}$ & $42.2 \mathrm{~b}$ \\
\hline & $146-152$ & $7.8 \mathrm{c}$ & $10.9 \mathrm{a}$ & $0.33 \mathrm{c}$ & $26.7 \mathrm{c}$ \\
\hline \multirow[t]{4}{*}{ Santana } & $120-126$ & $9.2 \mathrm{a}$ & $11.4 \mathrm{~b}$ & $1.06 \mathrm{a}$ & $46.6 \mathrm{a}$ \\
\hline & $127-133$ & $9.2 \mathrm{a}$ & $11.7 \mathrm{~b}$ & $0.92 \mathrm{~b}$ & $42.2 \mathrm{a}$ \\
\hline & $134-140$ & $8.2 \mathrm{~b}$ & $11.9 \mathrm{a}$ & $0.79 \mathrm{c}$ & $32.1 \mathrm{~b}$ \\
\hline & $141-147$ & $7.4 \mathrm{c}$ & $12.4 \mathrm{a}$ & $0.51 \mathrm{~d}$ & $22.3 \mathrm{c}$ \\
\hline \multirow[t]{4}{*}{ Sultanat } & $125-131$ & $10.2 \mathrm{a}$ & $10.5 \mathrm{~b}$ & $0.98 \mathrm{a}$ & $56.1 \mathrm{a}$ \\
\hline & $132-138$ & $10.1 \mathrm{a}$ & $11.5 \mathrm{a}$ & $0.82 \mathrm{~b}$ & $53.1 \mathrm{a}$ \\
\hline & $139-145$ & $8.8 \mathrm{~b}$ & $11.7 \mathrm{a}$ & $0.71 \mathrm{~b}$ & $32.4 \mathrm{~b}$ \\
\hline & $146-152$ & $8.5 \mathrm{~b}$ & $11.9 \mathrm{a}$ & $0.58 \mathrm{c}$ & $21.3 \mathrm{c}$ \\
\hline \multirow[t]{4}{*}{ Zarya Alatau } & $120-126$ & $11.2 \mathrm{a}$ & $11.4 \mathrm{a}$ & $0.92 \mathrm{a}$ & $89.1 \mathrm{a}$ \\
\hline & $127-133$ & $9.2 \mathrm{~b}$ & $11.3 \mathrm{a}$ & $0.74 \mathrm{~b}$ & $74.3 \mathrm{~b}$ \\
\hline & $134-140$ & $8.3 \mathrm{c}$ & $11.2 \mathrm{a}$ & $0.50 \mathrm{c}$ & $61.3 \mathrm{c}$ \\
\hline & $141-147$ & $7.2 \mathrm{~d}$ & $11.8 \mathrm{a}$ & $0.33 \mathrm{~d}$ & $52.73 \mathrm{c}$ \\
\hline
\end{tabular}

\begin{tabular}{|c|c|c|c|c|}
\hline Agra & NS & NS & NS & NS \\
\hline Eir & $* *$ & $*$ & $*$ & NS \\
\hline Ella & NS & NS & NS & NS \\
\hline Dayton & NS & NS & NS & NS \\
\hline Delorina & NS & NS & NS & NS \\
\hline Santana & NS & NS & NS & NS \\
\hline Sultanat & $* * *$ & $*$ & $*$ & NS \\
\hline Zarya Alatau & NS & NS & NS & $*$ \\
\hline
\end{tabular}

${ }^{\mathrm{z}}$ Values are means of three years, three replicates of 30 fruits each.

${ }^{y}$ Values for each cultivar/column with the same letter are not statistically different at $P \leq 0.001$.

${ }^{x}$ Days after full bloom.

${ }^{\text {w}}$ Fruit color expressed as hue angle $(\mathrm{H}) ; \mathrm{SSC}=$ soluble solid concentration and $\mathrm{TA}=$ titratable acid expressed as malic acid.

$\mathrm{NS}, *, * *$, and $* * *$ nonsignificant or significant differences at $P \leq 0.05,0.01$, or 0.001 , respectively.

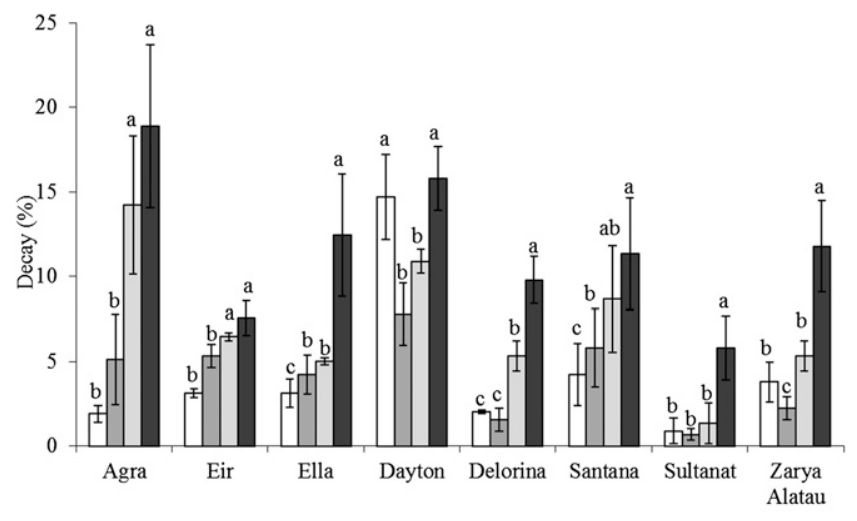

口First harvest $\quad \square$ Second harvest $\quad$ QThird harvest $\quad$ GFourth harvest

Fig. 2. The incidence of fungal decay of different cultivars grown in an organic orchard and picked at different dates. Percentage fruit that had decayed as a result of fungi during cold storage in air for four months is indicated on the y-axis. Values are means of three years with three replicates of 40 fruits each. Within each cultivar, bars with the same letter are not statistically different at $P \leq 0.001$. Significant interactions $(P \leq 0.05)$ were found between season and harvesting date for decay in 'Agra', 'Ella', 'Delorina', and 'Zarya Alatau'. 
Table 5. Changes in fruit quality during storage in air for four months, for eight apple cultivars grown in an organic orchard and picked at different times. ${ }^{2}$

\begin{tabular}{|c|c|c|c|c|c|}
\hline Cultivar & Harvest week DAFB ${ }^{x}$ & Firmness $\left(\mathrm{kg} \cdot \mathrm{cm}^{-2}\right)$ & $\mathrm{SSC}^{\mathrm{w}}(\%)$ & $\mathrm{TA}^{\mathrm{w}}(\%)$ & Color $\left(\mathrm{H}^{\circ}\right)^{\mathrm{w}}$ \\
\hline \multirow[t]{4}{*}{ Agra } & $95-101$ & $4.8 \mathrm{a}^{\mathrm{y}}$ & $11.5 \mathrm{a}$ & $0.46 \mathrm{a}$ & $19.0 \mathrm{a}$ \\
\hline & $102-108$ & $3.4 \mathrm{~b}$ & $11.2 \mathrm{a}$ & $0.35 \mathrm{~b}$ & $16.5 \mathrm{a}$ \\
\hline & $109-115$ & $2.5 \mathrm{bc}$ & $10.8 \mathrm{~b}$ & $0.24 \mathrm{c}$ & $19.8 \mathrm{a}$ \\
\hline & $116-122$ & $2.0 \mathrm{c}$ & $10.3 \mathrm{~b}$ & $0.18 \mathrm{c}$ & $20.7 \mathrm{a}$ \\
\hline \multirow[t]{4}{*}{ Eir } & $100-106$ & $4.4 \mathrm{a}$ & $11.7 \mathrm{a}$ & $0.46 \mathrm{a}$ & $17.5 \mathrm{a}$ \\
\hline & $107-113$ & $4.3 \mathrm{a}$ & $11.7 \mathrm{a}$ & $0.30 \mathrm{~b}$ & $8.4 \mathrm{~b}$ \\
\hline & $114-120$ & $3.4 \mathrm{~b}$ & $11.1 \mathrm{~b}$ & $0.19 \mathrm{c}$ & $15.0 \mathrm{a}$ \\
\hline & $121-127$ & $2.2 \mathrm{c}$ & $10.9 \mathrm{~b}$ & $0.15 \mathrm{c}$ & $11.8 \mathrm{ab}$ \\
\hline \multirow[t]{4}{*}{ Ella } & $105-111$ & $4.2 \mathrm{a}$ & $10.5 \mathrm{~b}$ & $0.75 \mathrm{a}$ & $99.3 \mathrm{~b}$ \\
\hline & $112-118$ & $4.3 \mathrm{a}$ & $11.2 \mathrm{ab}$ & $0.65 \mathrm{~b}$ & $115.6 \mathrm{a}$ \\
\hline & $119-125$ & $3.1 \mathrm{~b}$ & $11.8 \mathrm{a}$ & $0.54 \mathrm{c}$ & $10.1 \mathrm{c}$ \\
\hline & $126-132$ & $2.9 \mathrm{~b}$ & $10.9 \mathrm{~b}$ & $0.16 \mathrm{~d}$ & $17.4 \mathrm{c}$ \\
\hline \multirow[t]{4}{*}{ Dayton } & $120-126$ & $5.1 \mathrm{~b}$ & $12.1 \mathrm{a}$ & $0.73 \mathrm{a}$ & $57.4 \mathrm{a}$ \\
\hline & $127-133$ & $5.9 \mathrm{a}$ & $11.7 \mathrm{a}$ & $0.69 \mathrm{a}$ & $25.0 \mathrm{~b}$ \\
\hline & $134-140$ & $4.4 \mathrm{c}$ & $11.4 \mathrm{ab}$ & $0.59 \mathrm{~b}$ & $21.1 \mathrm{~b}$ \\
\hline & $141-147$ & $4.2 \mathrm{c}$ & $11.0 \mathrm{~b}$ & $0.36 \mathrm{c}$ & $25.6 \mathrm{~b}$ \\
\hline \multirow[t]{4}{*}{ Delorina } & $125-131$ & $6.4 \mathrm{a}$ & $10.4 \mathrm{a}$ & $0.36 \mathrm{a}$ & $90.5 \mathrm{a}$ \\
\hline & $132-138$ & $5.0 \mathrm{~b}$ & $10.3 \mathrm{a}$ & $0.22 \mathrm{~b}$ & $43.0 \mathrm{~b}$ \\
\hline & 139-145 & $4.4 \mathrm{~b}$ & $10.6 \mathrm{a}$ & $0.11 \mathrm{c}$ & $22.8 \mathrm{c}$ \\
\hline & $146-152$ & $3.8 \mathrm{~b}$ & $10.1 \mathrm{a}$ & $0.04 \mathrm{c}$ & $28.3 \mathrm{c}$ \\
\hline \multirow[t]{4}{*}{ Santana } & $120-126$ & $5.7 \mathrm{~b}$ & $12.1 \mathrm{ab}$ & $0.84 \mathrm{a}$ & $55.9 \mathrm{a}$ \\
\hline & $127-133$ & $6.8 \mathrm{a}$ & $12.8 \mathrm{a}$ & $0.68 \mathrm{~b}$ & $50.2 \mathrm{a}$ \\
\hline & $134-140$ & $6.3 \mathrm{a}$ & $12.2 \mathrm{ab}$ & $0.65 \mathrm{~b}$ & $17.0 \mathrm{~b}$ \\
\hline & $141-147$ & $4.9 \mathrm{c}$ & $11.6 \mathrm{~b}$ & $0.38 \mathrm{c}$ & $13.6 \mathrm{~b}$ \\
\hline \multirow[t]{4}{*}{ Sultanat } & $125-131$ & $7.5 \mathrm{a}$ & $12.8 \mathrm{a}$ & $0.60 \mathrm{a}$ & $23.6 \mathrm{a}$ \\
\hline & $132-138$ & $7.2 \mathrm{a}$ & $13.5 \mathrm{a}$ & $0.45 \mathrm{~b}$ & $27.4 \mathrm{a}$ \\
\hline & $139-145$ & $6.2 \mathrm{~b}$ & $13.4 \mathrm{a}$ & $0.35 \mathrm{c}$ & $14.9 \mathrm{~b}$ \\
\hline & $146-152$ & $6.4 \mathrm{~b}$ & $13.0 \mathrm{a}$ & $0.30 \mathrm{c}$ & $10.4 \mathrm{~b}$ \\
\hline \multirow[t]{4}{*}{ Zarya Alatau } & $120-126$ & $6.0 \mathrm{a}$ & $13.1 \mathrm{a}$ & $0.50 \mathrm{a}$ & $91.0 \mathrm{a}$ \\
\hline & $127-133$ & $4.7 \mathrm{~b}$ & $11.6 \mathrm{~b}$ & $0.42 \mathrm{a}$ & $10.4 \mathrm{c}$ \\
\hline & $134-140$ & $4.6 \mathrm{~b}$ & $10.9 \mathrm{~b}$ & $0.28 \mathrm{~b}$ & $39.8 \mathrm{~b}$ \\
\hline & $141-147$ & $4.1 \mathrm{~b}$ & $10.7 \mathrm{~b}$ & $0.23 \mathrm{~b}$ & $48.5 \mathrm{~b}$ \\
\hline \multicolumn{6}{|c|}{ Interaction between the effect of harvesting date and year } \\
\hline Agra & & NS & NS & NS & NS \\
\hline Eir & & $* *$ & $*$ & $*$ & NS \\
\hline Ella & & NS & NS & NS & NS \\
\hline Dayton & & NS & NS & NS & NS \\
\hline Delorina & & NS & NS & NS & NS \\
\hline Santana & & NS & NS & NS & NS \\
\hline Sultanat & & $* * *$ & $*$ & $*$ & NS \\
\hline Zarya Alatau & & NS & NS & NS & $*$ \\
\hline
\end{tabular}

${ }^{\mathrm{z}}$ Values are means of three years with three replicates of 15 fruits each.

${ }^{y}$ Values for each cultivar/column with the same letter are not statistically different at $P \leq 0.001$.

${ }^{x}$ Days after full bloom.

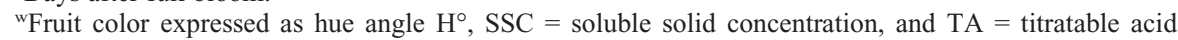
expressed as malic acid.

NS, *,**, and *** $=$ nonsignificant or significant differences at $P \leq 0.05,0.01$, or 0.001 , respectively.

Table 6. Pearson correlation between IEC (ethylene production, $\mu \mathrm{L} \cdot \mathrm{L}^{-1} \cdot \mathrm{kg}^{-1} \cdot \mathrm{h}^{-1}$ ) and starch conversion score (1-10), firmness $\left(\mathrm{kg} \cdot \mathrm{cm}^{-2}\right)$, soluble solids content (SSC; g/100 mL), titratable acidity (TA; in percent), and Streif index in eight apple cultivars grown in an organic orchard.

\begin{tabular}{lccccc}
\hline Cultivar & IEC and starch & IEC and firmness & IEC and SSC & IEC and TA & IEC and Streif index \\
\hline Agra & $0.83^{* * *}$ & $-0.74^{* * *}$ & $0.60^{* *}$ & $-0.81^{* * *}$ & $-0.69^{* *}$ \\
Eir & $0.70^{*}$ & $-0.70^{* *}$ & $0.76^{* * *}$ & $-0.77^{* * *}$ & $-0.71^{* * *}$ \\
Ella & $0.71^{* *}$ & $-0.57^{*}$ & $-0.02 \mathrm{NS}$ & $-0.78^{* * *}$ & $-0.57^{*}$ \\
Dayton & $0.75^{* *}$ & $-0.74^{* * *}$ & $0.53^{*}$ & $-0.73^{* *}$ & $-0.62^{*}$ \\
Delorina & $0.67^{*}$ & $-0.61^{*}$ & $0.41 \mathrm{NS}$ & $-0.78^{* * *}$ & $-0.77^{* * *}$ \\
Santana & $0.86^{* * *}$ & $-0.78^{* * *}$ & $0.58^{* *}$ & $-0.72^{* *}$ & $-0.63^{*}$ \\
Sultanat & $0.85^{* * *}$ & $-0.72^{* * *}$ & $0.33 \mathrm{NS}$ & $-0.77^{* * *}$ & $-0.56^{*}$ \\
Zarya Alatau & $0.75^{* *}$ & $-0.57^{*}$ & $0.62^{* *}$ & $-0.78^{* * *}$ & $-0.70^{* * *}$ \\
\hline
\end{tabular}

${ }^{\mathrm{z}}$ Streif index $=$ firmness $(\mathrm{SSC} \times \text { starch conversion score })^{-1}$.

NS, $* * *$, and $* * *=$ nonsignificant or significant differences at $P \leq 0.05,0.01$, or 0.001 , respectively.

ULO, whether $1.0 \mathrm{kPa}$ or $2.0 \mathrm{kPa} \mathrm{CO}_{2}$, helped to stabilize SSC in 'Agra', 'Dayton', and 'Zarya Alatau' and TA in 'Agra', 'Eir', 'Ella', 'Dayton', and 'Santana' $(P \leq 0.001$; Table 7). In 'Zarya Alatau', taste (acid:SSC ratio) was maintained better when stored in fruits stored in CA ( $P \leq 0.001$; Table 7). Amount of fungal decay decreased in 'Dayton' and 'Zarya Alatau' in all three years and in two of the years in 'Santana' and 'Sultanat' when the fruit was stored in ULO instead of CA $(P \leq 0.001$; Table 7$)$. However, the higher $\mathrm{CO}_{2}$ caused skin injury and flesh browning in 'Zarya Alatau' and 'Delorina' apples (data not shown).

\section{Discussion}

Orchard management. The SPRM management increased light availability in July and August in all six studied cultivars. This management also resulted in a significantly higher yield in five of the cultivars compared with the standard practice but did not affect fruit size.

Because summer pruning involves the removal of weak shoots and leaves with low photosynthesis and high respiration rate, it is likely to affect the leaf:fruit ratio and carbohydrate partitioning positively, thus adjusting cropload and improving fruit quality (Awad et al., 2001; Tahir et al., 2008). We did, however, not see any significant differences between SPRM and the control in SSC and TA at harvest, but there was significantly less decline in these parameters in fruit grown with SPRM when analyzed after storage.

Application of SPRM has also been shown to increase fruit coloration (Glenn and Puterka, 2007; Li et al., 2003), which in its turn is linked to an increased anthocyanin content (Sadilova et al., 2006). In our study, both anthocyanin and total phenolic content were higher in fruit produced with SPRM. In a previous study, the sun-exposed side of the fruit contained more wax than the shaded side (Tahir et al., 2009). Possibly both flavonoid content and wax accumulation as well as the retaining of firmness during storage may provide some physical protection or improved defense against pathogens as evidenced by the lower rate of fungal damage in fruit grown with SPRM.

Choice of harvesting date. Choice of an optimum harvesting date can help to maximize fruit quality and minimize storage disorders in organic apple production (Echeverría et al., 2002). Fruit storability is closely associated with the climacteric patterns of ethylene production (Elgar et al., 1998). Because the accelerated production of ethylene is one of the most important changes in apples as they begin to ripen, it can be used as an accurate indicator for determination of the optimum harvesting date (Genard and Gouble, 2005; Sanders and de Wild, 2003). Harvesting should be conducted in the pre-climacteric period, when no significant quantities of ethylene have yet been produced or, at least, before half of the fruits have reached the threshold level of autocatalytic ethylene production $\left(0.1 \mu \mathrm{L} \cdot \mathrm{L}^{-1} \cdot \mathrm{kg}^{-1} \cdot \mathrm{h}^{-1}\right)$ (Bulens et al., 2010). Our results similarly indicated that all of the eight investigated cultivars should be harvested when no more than a maximum of $50 \%$ of the fruit has started to produce ethylene to avoid storage decay and maintain quality. 


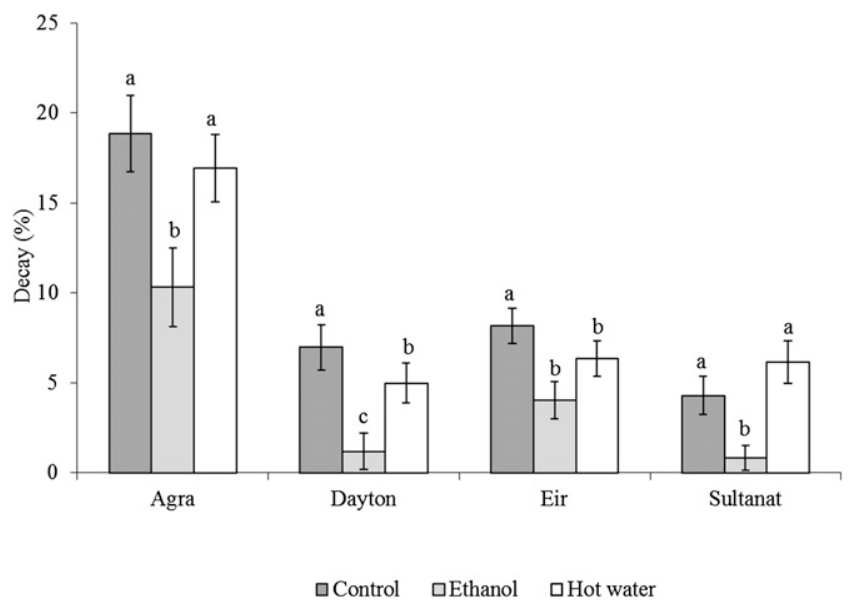

Fig. 3. Effect of postharvest treatments on the incidence of fungal decay. Values are means of two years with three replicates of five trees and eight fruits each. Within each cultivar, bars with the same letter are not statistically different at $P \leq 0.001$. No interaction between season and treatment for fungal decay was found.
However, early-ripening cultivars showed rapid acceleration in IEC and had a short harvesting period and limited storage life. The IEC in 'Agra', 'Eir', and 'Ella' thus remained at the threshold level for only 1 week compared with 2 weeks in the other five cultivars.

For practical reasons, a more commonly used method for determination of optimum harvesting date is the starch hydrolysis, i.e., the degradation of starch per interval of time (Peirs et al., 2004). This remained stable overall three years, and was in very close agreement (for 'Agra', 'Santana', and 'Sultanat') or close agreement (for 'Dayton', 'Ella', and 'Zarya Alatau') with the increase in ethylene production. Fruits picked before a significant change in starch hydrolysis showed overall very good storability. According to the barely significant correlation $(P \leq 0.05)$ between IEC and starch conversion score for 'Eir' and

Table 7. Storage potential of eight apple cultivars grown in an organic orchard, evaluated as percentage of decayed fruit, softening, development of soluble solids content (SSC), and decline in titratable acid (TA) during storage with three different methods. ${ }^{.}$

\begin{tabular}{|c|c|c|c|c|c|c|c|c|}
\hline Cultivar & Storage method & Firmness $\left(\mathrm{kg} \cdot \mathrm{cm}^{-2}\right)$ & Softening $(\%)^{\mathrm{w}}$ & $\mathrm{SSC}^{\mathrm{x}}(\%)$ & SSC development $(\%)^{\mathrm{w}}$ & $\mathrm{TA}^{\mathrm{x}}(\%)$ & TA decline $(\%)^{\mathrm{w}}$ & Decay $(\%)$ \\
\hline \multirow[t]{3}{*}{ Agra } & In air & $4.3 \mathrm{c}^{\mathrm{y}}$ & $51.0 \mathrm{a}$ & $12.0 \mathrm{a}$ & $16.2 \mathrm{a}$ & $0.25 \mathrm{~b}$ & $66.7 \mathrm{a}$ & $13.7 \mathrm{a}$ \\
\hline & ULO $1^{x}$ & $5.6 \mathrm{~b}$ & $36.0 \mathrm{~b}$ & $10.8 \mathrm{~b}$ & $4.7 \mathrm{c}$ & $0.66 \mathrm{a}$ & $11.3 \mathrm{c}$ & $5.6 \mathrm{~b}$ \\
\hline & ULO $2^{x}$ & $7.8 \mathrm{a}$ & $11.0 \mathrm{c}$ & $10.9 \mathrm{~b}$ & $5.6 \mathrm{c}$ & $0.66 \mathrm{a}$ & $10.5 \mathrm{c}$ & $5.8 \mathrm{~b}$ \\
\hline \multirow{3}{*}{ Eir } & CA & $4.5 \mathrm{a}$ & $44.0 \mathrm{a}$ & $11.0 \mathrm{a}$ & $6.5 \mathrm{a}$ & $0.53 \mathrm{~b}$ & $24.3 \mathrm{a}$ & $3.0 \mathrm{~b}$ \\
\hline & ULO 1 & $4.4 \mathrm{a}$ & $45.2 \mathrm{a}$ & $10.8 \mathrm{a}$ & $4.4 \mathrm{a}$ & $0.62 \mathrm{a}$ & $10.9 \mathrm{~b}$ & $2.5 \mathrm{~b}$ \\
\hline & ULO 2 & $4.0 \mathrm{a}$ & $50.1 \mathrm{a}$ & $11.0 \mathrm{a}$ & $6.6 \mathrm{a}$ & $0.61 \mathrm{a}$ & $12.2 \mathrm{~b}$ & $3.0 \mathrm{~b}$ \\
\hline \multirow{2}{*}{ Ella } & ULO 1 & $7.2 \mathrm{a}$ & $18.8 \mathrm{~b}$ & $11.6 \mathrm{a}$ & $11.3 \mathrm{a}$ & $0.76 \mathrm{a}$ & $7.5 \mathrm{c}$ & $2.2 \mathrm{~b}$ \\
\hline & ULO 2 & $7.7 \mathrm{a}$ & $13.7 \mathrm{~b}$ & $12.0 \mathrm{a}$ & $15.5 \mathrm{a}$ & $0.71 \mathrm{a}$ & $13.1 \mathrm{c}$ & $1.4 \mathrm{~b}$ \\
\hline \multirow[t]{4}{*}{ Dayton } & In air & $5.2 \mathrm{~b}$ & $34.6 \mathrm{a}$ & $12.8 \mathrm{a}$ & $11.2 \mathrm{a}$ & $0.52 \mathrm{c}$ & $24.2 \mathrm{a}$ & $6.6 \mathrm{a}$ \\
\hline & CA & $7.6 \mathrm{a}$ & $5.1 \mathrm{~b}$ & $12.4 \mathrm{ab}$ & $7.8 \mathrm{~b}$ & $0.62 \mathrm{~b}$ & $9.1 \mathrm{~b}$ & $2.9 \mathrm{~b}$ \\
\hline & ULO 1 & $7.4 \mathrm{a}$ & $6.9 \mathrm{~b}$ & $12.0 \mathrm{~b}$ & $4.4 \mathrm{c}$ & $0.65 \mathrm{ab}$ & $3.7 \mathrm{c}$ & $2.0 \mathrm{~b}$ \\
\hline & ULO 2 & $7.2 \mathrm{a}$ & $9.9 \mathrm{~b}$ & $12.0 \mathrm{~b}$ & $4.1 \mathrm{c}$ & $0.67 \mathrm{a}$ & $2.1 \mathrm{c}$ & $0.7 \mathrm{c}$ \\
\hline Delorina & In air & $5.7 \mathrm{c}$ & $39.1 \mathrm{a}$ & $12.1 \mathrm{a}$ & $15.1 \mathrm{a}$ & $0.34 \mathrm{~b}$ & $51.6 \mathrm{a}$ & $10.2 \mathrm{a}$ \\
\hline \multirow{2}{*}{ Santana } & ULO 1 & $7.3 \mathrm{a}$ & $17.3 \mathrm{~b}$ & $12.2 \mathrm{~b}$ & $3.3 \mathrm{~b}$ & $0.62 \mathrm{~b}$ & $12.5 \mathrm{c}$ & $3.8 \mathrm{bc}$ \\
\hline & ULO 2 & $7.6 \mathrm{a}$ & $13.7 \mathrm{~b}$ & $12.1 \mathrm{~b}$ & $2.9 \mathrm{~b}$ & $0.73 \mathrm{a}$ & $12.7 \mathrm{c}$ & $2.1 \mathrm{c}$ \\
\hline \multirow[t]{4}{*}{ Sultanat } & In air & $5.0 \mathrm{c}$ & $45.5 \mathrm{a}$ & $13.1 \mathrm{a}$ & $13.0 \mathrm{a}$ & $0.54 \mathrm{c}$ & $29.6 \mathrm{a}$ & $4.6 \mathrm{a}$ \\
\hline & CA & $7.3 \mathrm{~b}$ & $20.5 \mathrm{~b}$ & $12.8 \mathrm{a}$ & $10.3 \mathrm{a}$ & $0.66 \mathrm{~b}$ & $12.7 \mathrm{~b}$ & $1.1 \mathrm{~b}$ \\
\hline & ULO 1 & $6.9 \mathrm{~b}$ & $24.7 \mathrm{~b}$ & $12.7 \mathrm{a}$ & $9.6 \mathrm{a}$ & $0.65 \mathrm{~b}$ & $10.0 \mathrm{~b}$ & $1.0 \mathrm{~b}$ \\
\hline & ULO 2 & $8.2 \mathrm{a}$ & $11.3 \mathrm{c}$ & $12.9 \mathrm{a}$ & $11.2 \mathrm{a}$ & $0.75 \mathrm{a}$ & $14.2 \mathrm{~b}$ & $0.2 \mathrm{c}$ \\
\hline \multirow[t]{4}{*}{ Zarya Alatau } & In air & $6.9 \mathrm{~b}$ & $23.2 \mathrm{a}$ & $11.7 \mathrm{a}$ & $3.6 \mathrm{a}$ & $0.60 \mathrm{~b}$ & $20.0 \mathrm{a}$ & $5.0 \mathrm{a}$ \\
\hline & CA & $8.0 \mathrm{a}$ & $11.0 \mathrm{~b}$ & $11.9 \mathrm{a}$ & $5.4 \mathrm{a}$ & $0.72 \mathrm{a}$ & $4.0 \mathrm{~b}$ & $1.5 \mathrm{~b}$ \\
\hline & ULO 1 & $8.2 \mathrm{a}$ & $8.8 \mathrm{~b}$ & $11.5 \mathrm{a}$ & $1.4 \mathrm{~b}$ & $0.70 \mathrm{a}$ & $6.9 \mathrm{~b}$ & $0.5 \mathrm{c}$ \\
\hline & ULO 2 & $7.9 \mathrm{a}$ & $12.1 \mathrm{~b}$ & $11.4 \mathrm{a}$ & $1.0 \mathrm{~b}$ & $0.62 \mathrm{~b}$ & $9.5 \mathrm{~b}$ & $0.3 \mathrm{c}$ \\
\hline
\end{tabular}

\begin{tabular}{|c|c|c|c|c|c|c|c|}
\hline \multicolumn{8}{|c|}{ Interaction between year and storage methods } \\
\hline Agra & $*$ & $*$ & NS & NS & NS & NS & NS \\
\hline Eir & NS & NS & NS & NS & $*$ & $*$ & $* *$ \\
\hline Ella & $* *$ & $* *$ & NS & NS & $* *$ & $* *$ & NS \\
\hline Dayton & NS & NS & NS & NS & NS & NS & $* *$ \\
\hline Delorina & NS & NS & NS & NS & NS & NS & $* * *$ \\
\hline Santana & NS & NS & NS & NS & $*$ & $*$ & NS \\
\hline Sultanat & $* * *$ & $* * *$ & NS & NS & $* *$ & $* *$ & $* * *$ \\
\hline Zarya Alatau & NS & NS & NS & NS & NS & NS & NS \\
\hline
\end{tabular}

${ }^{2}$ Values are means of three years and three replicates of 30 fruits each.

${ }^{y}$ Values for each cultivar/column with the same letter are not statistically different at $P \leq 0.001$.

${ }^{\mathrm{x}} \mathrm{CA}=$ controlled atmosphere storage $\left(2.0 \mathrm{kPa} \mathrm{O}_{2}\right.$ and $\left.2.0 \mathrm{kPa} \mathrm{CO}_{2}\right) ; \mathrm{ULO}=$ ultra-low oxygen (ULO $1: 1.0 \mathrm{kPa} \mathrm{O}$ and $1.0 \mathrm{kPa} \mathrm{CO}_{2}$ and $\mathrm{ULO}_{2}: 1.0 \mathrm{kPa} \mathrm{O}_{2}$ and $2.0 \mathrm{kPa} \mathrm{CO}$ ), $\mathrm{SSC}=$ soluble solid concentration; $\mathrm{TA}=$ titratable acid.

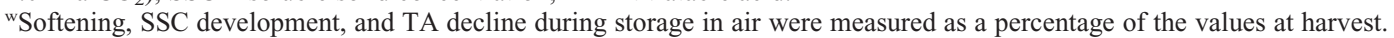

Ns, *,**, and *** = nonsignificant or significant differences at $P \leq 0.05,0.01$, or 0.001 , respectively. 
'Delorina', the latter cannot be used as a maturity index in these two cultivars, confirming previous data showing that starch conversion has a somewhat limited value as a maturation index (Peirs et al., 2004).

The Streif index, which makes use of three parameters: fruit firmness, SSC, and starch hydrolysis (Delong et al., 1999; Streif, 1996), is a commonly used method for determination of harvesting date. In our study, especially 'Eir', 'Delorina', and 'Zarya Alatau', and, to a somewhat lesser extent, 'Agra', showed a strong correlation between the Streif index and IEC, indicating that this index is very useful for determination of optimum harvest date in many cultivars.

The rise in ethylene production was closely associated also with fruit firmness and TA and to a lesser extent with SSC. Using these parameters for determination of optimal harvesting date will be less accurate because they are strongly cultivar- and environmentdependent (Willats et al., 2001). As a result of the widely varying weather conditions, it was not possible to obtain estimates of color development that could be used as a maturity index.

Post-harvest treatments. The protective effects resulting from post-harvest heating of the fruit may derive from enhancement of the wound repair process, inhibition of the synthesis of cell wall hydrolytic enzymes (Ben-Shalom et al., 1996), and changes in apple skin structure (Tahir et al., 2009). Hot water can melt skin wax, fill microwounds, and stimulate wax recrystallization, thus improving the protective ability of the fruit surface (Díaz-Pérez et al., 2001; Fallik, 2006; Roy et al., 1994).

The efficiency of hot water treatment to reduce storage decay appears to be cultivarspecific (Spadaro et al., 2004). According to our present results, this treatment provides only a minor improvement for the four tested cultivars. By contrast, application of ethanol resulted in a significant decrease in fungal decay for all four cultivars, thereby confirming previous reports on how ethanol application can control post-harvest pathogens in mango (Gutiérrez-Alonso et al., 2004; GutiérrezMartínez et al., 2012; Plotto et al., 2006), grape (Chervin et al., 2005), and peaches and nectarines (Margosan et al., 1997).

Storage conditions. The main benefits of CA and ULO are that the storage period can be prolonged; fruit quality is maintained for a longer period and fewer problems with physiological disorders are encountered (Brackman et al., 1994; Graell et al., 1997; López et al., 2000). Our results similarly indicate that CA storage is very beneficial for retaining quality of organic fruit with a large improvement especially in firmness and TA. Even more pronounced effects were obtained for incidence of fungal decay, which was significantly lower in CA-stored fruit of all cultivars compared with fruit in regular air storage. Storage of these cultivars in a different range of $\mathrm{pCO}_{2}$ achieved slight additional improvements in some cultivars, but high $\mathrm{CO}_{2}$ can also increase disorders. Thus,
ULO $1\left(1.0 \mathrm{kPa} \mathrm{O}\right.$ and $\left.1.0 \mathrm{kPa} \mathrm{CO} \mathrm{CO}_{2}\right)$ decreased fungal decay and improved taste in 'Zarya Alatau', whereas ULO $2(1.0 \mathrm{kPa} \mathrm{O}$ and $2.0 \mathrm{kPa} \mathrm{CO}_{2}$ ) caused flesh browning in this cultivar. Fruits of 'Dayton' and 'Sultanat' responded well to ULO 2 because storage decay decreased and taste improved in comparison with ULO 1 and CA. ULO 2 also decreased storage decay in 'Santana'. In conclusion, $\mathrm{CA}\left(2.0 \mathrm{kPa} \mathrm{O} \mathrm{O}_{2}\right.$ and $2.0 \mathrm{kPa}$ $\mathrm{CO}_{2}$ ) can be recommended for 'Agra', 'Eir', 'Ella', and 'Delorina'; ULO 1 for 'Zarya Alatau'; and ULO 2 for 'Dayton', 'Santana', and 'Sultanat'.

\section{Conclusions}

Orchard floor management in combination with summer pruning improved fruit color and flavonoid content in all investigated cultivars. This practice also increased yield and improved fruit storability in all cultivars except 'Ella'. Organically grown summer apples showed poor storage potential, whereas late-ripening cultivars such as 'Sultanat' and 'Dayton' had good resistance to fungal incidence. Starch hydrolysis can be used as a maturity index for some organically grown cultivars ('Agra', 'Santana', and 'Sultanat'), whereas the Streif index would be preferable for other cultivars ('Eir', 'Delorina', and 'Zarya Alatau'). Ethanol appears promising as a natural product for protection against storage decay. Carefully tailored ULO storage conditions can improve the storage potential substantially.

\section{Literature Cited}

Ascard, J., B. Håkansson, A. Hansson, H. Stridh, and M. Söderlind. 2010. Cost price calculations for organically and conventionally grown apples in Sweden. <http://www.ecofruit.net/2010/46 RP_J_Ascard_B_Hakansson_A_Hansson_et_al_ S304bis312.pdf $>$.

Awad, M.A., A. De Jager, M. Dekker, and W.M.F. Jongen. 2001. Formation of flavonoids and chlorogenic acid in apples as affected by crop load. Sci. Hort. 91:227-237.

Ben Shalom, N., J. Hanzon, R. Pinto, and S. Lurie. 1996. Cell wall changes and partial prevention of fruit softening in prestorage heat treated 'Anna' apples. J. Sci. Food Agr. 72:231-234.

Blanke, M. 2008. Alternatives to reflective mulch cloth (Extenday ${ }^{\mathrm{TM}}$ ) for apple under hail net? Sci. Hort. 116:223-226.

Brackman, A., J. Streif, and F. Bangerth. 1994. Influence of CA and ULO storage conditions on quality parameters and ripening of preclimacteric and climacteric harvested apples. Gartenbauwissenschaft 59:252-257.

Bulens, I., B. Van de Poel, M.L.A.T.M. Hertog, A.H. Geeraerd, and B.M. Nicolaï. 2010. Modeling of ethylene biosynthesis during ripening and CA storage of 'Jonagold' apples. Acta Hort. 876:85-90.

Chervina, Ch., P. Westercampb, and G. Monteilsb. 2005. Ethanol vapours limit Botrytis development over the postharvest life of table grapes. Postharvest Biol. Technol. 36:319-322.

Conway, W.S., B. Leverentz, W.J. Janisiewicz, A.B. Blodgett, R.A. Saftner, and M.J. Camp. 2004. Integrating heat treatment, biocontrol and sodium bicarbonate to reduce postharvest decay of apple caused by Colletotrichum acutatum and Penicillium expansum. Postharvest Biol. Technol. 34:11-20.

de Castro, E., W.V. Biasi, and E.J. Mitcham. 2007. Quality of Pink Lady apples in relation to maturity at harvest, prestorage treatments, and controlled atmosphere during storage. HortScience 42:605-610.

Delate, K., A. McKern, R. Turnbull, J. Walker, R. Volz, A. White, V. Bus, D. Rogers, L. Cole, N. How, S. Guernsey, and J. Johnston. 2003. Organic apple systems: Constraints and opportunities for producers in local and global markets: Introduction to the colloquium. HortScience 43:6-11.

Delong, J.M., R.K. Prange, P.A. Harrison, R.A. Schofield, and J.R. DeEll. 1999. Using the Streif index as a final harvest window for controlledatmosphere storage of apples. HortScience 4. 1251-1255.

Delong, J.M., R.K. Prange, W.C. Schotsmans, D.S. Nichols, and P.A. Harrison. 2009. Determination of the optimal pre-storage delayed cooling regime to control disorders and maintain quality in 'Honeycrisp'тм apples. J. Hort. Sci. Biotechnol. 84:410-414.

Dewanto, V., X.Z. Wu, K.K. Adom, and R.H. Liu. 2002. Thermal processing enhances the nutritional value of tomatoes by increasing total antioxidant activity. J. Agr. Food Chem. 50: 3010-3014.

Díaz-Pérez, J.C., A. Mejía, S. Bautista, R. Zavaleta, R. Villanueva, and R. López-Gómez. 2001. Response of sapote mamey [Pouteria sapota (Jacq.) H.E. Moore \& Stearn] fruit to hot water treatments. Postharvest Biol. Technol. 22:159_ 167.

Echeverría, G., J. Graell, and M.L. López. 2002. Effect of harvest date and storage conditions on quality and aroma production of 'Fuji' apples. Food Sci. Technol. Int. 8:351-360.

Elgar, H.J., D.M. Burmeister, and C.B. Watkins. 1998. Storage and handling effects on a $\mathrm{CO}_{2}$ related internal browning disorder of 'Braeburn' apples. HortScience 33:719-722.

Fallik, E. 2006. Hot water treatments for control of fungal decay on fresh produce, p. 461-477. In: Sapers, G.M., J.R. Gorny, and A.E. Yousef (eds.). Microbiology of fruits and vegetables. Taylor and Francis, Boca Raton, FL.

Fawbush, F., J.F. Nock, and C.B. Watkins. 2008. External carbon dioxide injury and 1- methylcyclopropene. Postharvest Biol. Technol. 48:92-98.

Funke, K. and M. Blanke. 2005. Can reflective ground cover enhance fruit quality and colouration? J. Food Agr. Environ. 3:203-206.

Genard, M. and B. Gouble. 2005. ETHY. A theory of fruit climacteric ethylene emission. Plant Physiol. 139:531-545.

Glenn, D.M. and G.J. Puterka. 2007. The use of plastic films and sprayable reflective particle films to increase light penetration in apple canopies and improve apple color and weight. HortScience 42:91-96.

Graell, J., C. Larrigaudiere, and M.L. López. 1997. Effect of low-oxygen atmospheres on quality and superficial scald of 'Topred' apples. Food Sci. Technol. Int. 3:203-211.

Gutiérrez-Alonso, J.G., O. Gutiérrez-Alonso, D. Nieto-Ángel, D. Téliz-Ortiz, E. Zavaleta-Mejía, and F. Delgadillo-Sánchez. 2004. Integrated management of mango (Mangifera indica L.) anthracnose [Colletotrichum gloeosporioides (Penz.) Penz. \& Sacc.] during postharvest. J. Mexican Phytopathol. 23:395-402.

Gutiérrez-Martínez, O., S.G. Osuna-López, M. Calderón-Santoyo, A. Cruz-Hernández, and S. Bautista-Baños. 2012. Influence of ethanol 
and heat on disease control and quality in stored mango fruits. Food Sci. Technol. 45:20-27.

Herencia, J.F., J.C. Ruiz-Porras, S. Melero, P.A. Garcia-Galavis, E. Morillo, and C. Maqueda. 2007. Comparison between organic and mineral fertilization for soil fertility levels, crop management concentrations and yield. Agron. J. 99:973-983.

Jönsson, А. 2007. Organic apple production in Sweden. Diss., Sweden University of Agricultural Science, Acta Universitatis Agriculturae Sueciae, 1652-6880, No. 14.

Jönsson, А. and H. Nybom. 2007. Consumer evaluation of scab-resistant apple cultivars in Sweden. Agr. Food Sci. 15:388-401.

Jönsson, А. and I. Tahir. 2004. Evaluation of scab resistant apple cultivars in Sweden. J. Fruit Ornament. 12:223-232.

Karabulut, O.A., F. Mlikota Gabler, M. Mansour, and J.L. Smilanick. 2004. Postharvest ethanol and hot water treatments of table grapes to control gray mold. Postharvest Biol. Technol. 34:169-177.

Lafer, G. 2006. Storability and fruit quality of 'Golden Delicious' as affected by harvest date, AVG and 1-MCP treatments. J. Fruit Ornament. 14:203-212.

Li, K., A. Lakso, R. Piccioni, and T. Robinson. 2003. Summer pruning effects on fruit size, fruit quality, return bloom and fine root survival. J. Hort. Sci. Biotechnol. 78:755-761.

Lima, G., F. De Curtis, R. Castoria, and V. De Cicco. 2003. Integrated control of apple postharvest pathogens and survival of biocontrol yeasts in semi-commercial conditions. Eur. J. Plant Pathol. 109:341-349.

López, M.S., T. Lavilla, I. Recasens, J. Graell, and M. Vendrell. 2000. Changes in aroma quality of 'Golden Delicious' apples after storage at different oxygen and carbon dioxide concentrations. J. Sci. Food Agr. 80:311-324.

Margosan, D.A., J.L. Smilanick, G.F. Simmons, and J.D. Henson. 1997. Combination of hot water and ethanol to control postharvest decay of peaches and nectarines. Plant Dis. 81: 1405-1409.
Maxin, P., R. Weber, H. Pedersen, and M. Williams. 2012. Control of a wide range of storage rots in naturally infected apples by hot-water dipping and rinsing. Postharvest Biol. Technol. 70: 25-31.

McGuire, R.G. 1992. Reporting of objective colour measurements. HortScience 27:1254-1255.

Paull, R.E. and N.J. Chen. 2000. Heat treatment and fruit ripening. Postharvest Biol. Technol. 21:21-37.

Peirs, A., J. Lammertyn, K. Ooms, and B.M. Nicolaï. 2004. Prediction of the optimal picking date of different apple cultivars by means of VIS/NIR-spectroscopy. Postharvest Biol. Technol. 21:189-199.

Plotto, A., J. Bai, J.A. Narciso, J.K. Brecht, and E.A. Baldwin. 2006. Ethanol vapor prior to processing extends fresh-cut mango storage by decreasing spoilage, but does not always delay ripening. Postharvest Biol. Technol. 39:134-145.

Rizzolo, A., M. Grassi, and P.E. Zerbini. 2006. Influence of harvest date on ripening and volatile compounds in the scab-resistant apple cultivar 'Golden Orange'. J. Hort. Sci. Biotechnol. 81:681-690.

Roy, S., W.S. Conway, A.E. Watada, C.E. Sams, E.F. Erbe, and W.P. Wergin. 1994. Heat treatment affects epicuticular wax structure and postharvest calcium uptake in 'Golden Delicious' apples. HortScience 29:1056-1058.

Sadilova, E., F.C. Stintzing, and R. Carle. 2006. Chemical quality parameters and anthocyanin pattern of red-fleshed W'Eir'ouge apples. J. Appl. Bot. Food Quality 80:82-87.

Sanders, M.G. and H.P.J. de Wild. 2003. The relation between in vivo ethylene production and oxygen partial pressure. Postharvest Biol. Technol. 30:143-151.

Sandskär, B. 2005. Pests in fruit (Skadegörare $\mathrm{i}$ frukt). The Swedish Board of Agriculture (SJV), Jönköping, Sweden. 2012. <http://www. jordbruksverket.se/amnesomraden/miljoochklimat/ ekologiskproduktion/reglerochcertifiering. 4.7850716f11cd786b52d80001031.html>.

Spadaro, D., A. Garibaldi, and M.L. Gullino. 2004. Control of Penicillium expansum and Botrytis cinerea on apple combining a biocontrol agent with hot water dipping and acibenzolar-Smethyl, baking soda, or ethanol application. Postharvest Biol. Technol. 33:141-151.

Streif, J. 1996. Optimum harvest date for different apple cultivars in the 'Bodensee' area, p. 15-20. In: De Jager A., D. Johnson, and E. Hohn (eds.). The postharvest treatment of fruit and vegetables: Determination and prediction of optimum harvest date of apple and pears. COST 94, Brussels, Belgium.

Tahir, I., E. Johansson, and M.E. Olsson. 2005. Groundcover materials improve quality and storability of 'Aroma' apples. HortScience 40: 1416-1420.

Tahir, I., E. Johansson, and M.E. Olsson. 2008. Improving the productivity, quality, and storability of 'Katja' apple by better orchard management procedures. HortScience 43:725-729.

Tahir, I., E. Johansson, and M.E. Olsson. 2009. Improvement of apple quality and storability by a combination of heat treatment and controlled atmosphere storage. HortScience 44:16481654.

Varela, P., A. Salvador, and S. Fiszman. 2005 Shelf-life estimation of 'Fuji' apples: Sensory characteristics and consumer acceptability. Postharvest Biol. Technol. 38:18-24.

Vielma, M.S., F.B. Matta, and J.L. Silval. 2008. Optimal harvest time of various apple cultivars grown in Northern Mississippi. J. Amer. Pomol. Soc. 62:13-20.

Weibel, F. 2002. Soil management and in-row weed control in organic apple production. Compact Fruit Tree 35:118-121.

Willats, W.G.T., L. McCartney, W. Mackie, and J.P. Knox. 2001. Pectin: Cell biology and prospects for functional analysis. Plant Mol. Biol. 47:9-27.

Wrolstad, R.E. 1993. Color and pigment analyses in fruit products. <http://www.nutraceutical institute.com $/$ methods $>$.

Zhang, W., X. Li, X.X. Wang, G.Y. Wang, J.T. Zheng, and D.C. Abeisinghe. 2007. Ethanol vapour alleviates postharvest decay and maintains fruit quality in Chinese bayberry. Postharvest Biol. Technol. 46:195-198. 